COBISS: 1.01

\title{
KRAŠKA PRESIHAJOČA JEZERA PIVKE (JZ SLOVENIJA) OB VISOKIH VODAH NOVEMBRA 2000
}

\author{
INTERMITTENT KARST LAKES OF PIVKA BASIN \\ (SW SLOVENIA) \\ DURING HIGH WATERS IN NOVEMBER 2000
}

\author{
GREGOR KOVAČIČ $\check{1}^{1} \&$ ŠPELA HABIČ $\check{C}^{2}$
}

\begin{abstract}
${ }^{1}$ Univerza na Primorskem, Fakulteta za humanistične študije Koper, Oddelek za geografijo, Glagoljaška 8, SI-6000 Koper, Slovenija

e-mail: gregor.kovacic@fhs-kp.si
\end{abstract}

${ }^{2}$ Volaričeva 20, SI-6230 Postojna, Slovenija

e-mail: spela.habic@zgs.gov.si

Prejeto/received: 4. 8. 2005 
Izvleček

UDK: 556.538(497.4 Pivka):556.166

\section{Gregor Kovačič \& Špela Habič: Kraška presihajoča jezera Pivke (JZ Slovenija) ob visokih vodah novembra 2000}

Prispevek obravnava značilnosti 17 kraških presihajočih jezer Zgornje Pivke. V času dolgotrajnega deževja v novembru 2000, ko je izmerjena količina dežja več kot trikrat presegala povprečno mesečno količino padavin, se je voda, po več desetletjih, pojavila v vseh jezerih. Izjemoma so bile poplavljene tudi številne druge manjše kraške globeli, kjer ojezeritve še niso bile dokumentirane. S pomočjo terenskih meritev in interpretacijo letalskih posnetkov so bili izmerjeni vodostaji in površine jezer ter prostornina vode $\mathrm{v}$ njih.

Ključne besede: kraško presihajoče jezero, poplave na krasu, kraška hidrologija, Pivka, Slovenija.

\section{Abstract \\ UDC: 556.538(497.4 Pivka):556.166 \\ Gregor Kovačič \& Špela Habič: Intermittent karst lakes of Pivka basin (SW Slovenia) during high waters in November 2000}

The article presents the characteristics of the 17 intermittent karst lakes of Upper Pivka. During the extended precipitation in November 2000 , when the amount of precipitation was more than three times the average, all the lakes were flooded for the first time in several decades. Also several additional small karst depressions were flooded, where overflowing had never been recorded before. By combining field observations with the interpretation of aerial photographs the water level, the extent of the lakes and the volumes of containing water were calculated.

Key words: intermittent karst lake, floods on karst, karst hydrology, Pivka, Slovenia.

\section{UVOD}

V sušnem obdobju se reka Pivka pojavlja na stiku apnencev in flišnih kamnin v okolici Prestranka, samo nekaj kilometrov pred svojim ponorom v Postojnsko jamo. $\mathrm{V}$ času visokih vod se podzemeljske vode iz plitkega kraškega vodonosnika zgornjega dela doline (Zgornja Pivka) razlijejo na površje in zapolnijo strugo Pivke, ki takrat neprekinjeno teče od izvira pri Zagorju do ponora. Istočasno je na Zgornji Pivki poplavljenih tudi več manjših kraških globeli, ki se tako spremene v presihajoča kraška jezera. Zaradi stalnosti vsakoletnih poplav je med domačini za večino omenjenih kotanj v uporabi ledinsko ime jezero.

Temeljito študijo o kraški hidrologiji Zgornje Pivke ter hidroloških značilnostih presihajočih kraških jezer je podal Habič (1968a, 1968b, 1975), nekaj dodatnih informacij

\section{INTRODUCTION}

In dry seasons the Pivka river appears at the contact between limestones and flysch rocks near Prestranek, only a few kilometers ahead of its ponor into Postojnska jama. During high waters, the underground water from the shallow karst aquifer of the upper part of the basin (Upper Pivka) pour over the surface and fill the Pivka riverbed, which then runs continuously from a spring near Zagorje to the ponor. During the same period also several small karst depressions are flooded in Upper Pivka and changed into intermittent karst lakes. The majority of the usually flooded karst depressions in Upper Pivka are because of their regular annual flooding traditionally termed lakes.

A thorough study about the karst hydrology of the Upper Pivka and the hydrological 
o 15-ih presihajočih jezerih je bilo pred kratkim predstavljeno v Ravbar \& Šebela (2003). V tej izdaji, kjer so presihajoča jezera Pivke obdelana z različnih zornih kotov, so zbrane še številne dodatne značilnosti jezer.

V času izjemnih padavin novembra 2000 smo opazovali in preučili pojav presihajočih jezer na Zgornji Pivki. V mesecu novembru 2000 je količina padavin skoraj trikrat presegla povprečne mesečne vrednosti izmerjenih padavin v obdobju 1961-1990, kar se je odrazilo v izrazitem dvigu gladine podtalnice. Poleg običajno zalitih kraških globeli so bile $\mathrm{v}$ tem obdobju izjemoma pod vodo tudi nekatere globeli, kjer poplave še nikoli niso bile zabeležene.

$\mathrm{Z}$ metodo terenskega opazovanja in interpretacije zračnih posnetkov smo skupno evidentirali 17 običajno pojavljajočih se jezer. Proti severozahodu si sledijo Šembijsko jezero, Kalsko jezero, Laneno jezero, Bačko jezero, Kljunov ribnik, Veliki dol (za Kalcem), Veliko in Malo Zagorsko jezero, Veliko in Malo Drskovško jezero, Parsko jezero, Radohovsko jezero, Klenski dol, Palško jezero, Petelinjsko jezero, Krajnikov dol in Jeredovce. Poleg tega smo preučili tudi več drugih zalitih kraških globeli različnih velikosti, kot je recimo območje Narič nad Šembijskim jezerom, in pa obsežno poplavno območje v okolici Knežaka in Bača. $\mathrm{V}$ okviru preučevanja posameznih jezer smo v raziskavo vključili tudi nekaj neimenovanih poplavljenih vrtač manjšega obsega. S pomočjo izmerjenih vodostajev poplavljenih kraških globeli in računalniškim procesiranjem DMR (digitalni model reliefa) smo izračunali velikosti posameznih jezer in prostornine vode $\mathrm{v}$ njih. $\mathrm{Na}$ osnovi pridobljenih podatkov smo preučili značilnosti obravnavanih jezer ob visokih vodah v novembru 2000. characteristics of the intermittent karst lakes was presented by Habič (1968a, 1968b, 1975) and some other information about 15 of the lakes was recently described by Ravbar \& Šebela (2003). Several additional characteristics of the lakes are drawn together in this volume, describing the lakes from different aspects.

In the period of extraordinary precipitation in November 2000, the occurrence of the periodical lakes of the Upper Pivka was observed and studied. In November 2000, the amount of precipitation was more than three times the average monthly amount for the period 1961-1990, which resulted in the excessive rising of the water table. Exceptionally, not only the usually flooded karst depressions were filled with water, but also some others, where overflowing had never been recorded before.

By combining field observations with the interpretation of aerial photographs, as many as 17 regular lakes were recognized. Towards the northwest the following lakes occur: Šembijsko jezero, Kalsko jezero, Laneno jezero, Bačko jezero, Kljunov ribnik, Veliki dol (za Kalcem), Malo Zagorsko jezero, Veliko Zagorsko jezero, Veliko Drskovško jezero, Malo Drskovško jezero, Parsko jezero, Radohovsko jezero, Klenski dol, Palško jezero, Petelinjsko jezero, Krajnikov dol and Jeredovce. Furthermore several other flooded karst depressions of different extent were observed, such as Nariče, which is a part of Šembijsko jezero, and the extensive flooding area around Knežak and Bač. Some other unnamed small dolines flooded as parts of different lakes were included as well. By measuring the water level of the flooded karst depressions and computer processing of the DEM (digital elevation model), the extent of the lakes and the volumes of water were calculated. On the basis of the gathered data, the characteristics of the discussed lakes during the high waters in November 2000 were studied. 


\section{GEOLOŠKE IN HIDROLOŠKE OSNOVE}

Geološke, reliefne in hidrološke značilnosti Zgornje Pivke so podrobneje obdelane v ostalih člankih tega zbornika. V tem poglavju so povzete bistvene ugotovitve, predvsem pa so obrazloženi vzroki pojavljanja kraških presihajočih jezer.

\section{GEOLOGICAL AND HYDROLOGICAL BASIS}

The geological, geomorphological and hydrological characteristics of the Upper Pivka valley are explained in other papers of this volume. In this chapter some of the most significant facts are repeated, principally the reasons for the appearance of the karst periodical lakes are described.
Slika 1: Dolina Zgornje Pivke s kraškimi presihajočimi jezeri in poplavljenimi površinami (november 2000). Poplave vzdolž struge Pivke niso označene. Legenda: 1. jezero in poplavna površina 2. srednji vodostaj Palškega jezera 3. površinski tok med jezeri 4. reka Pivka s pritoki 5. naselje 6. grad Kalc 7. površje pod $600 \mathrm{~m}$ n.v. 8. površje nad $600 \mathrm{~m}$ n.v.

Figure 1: The valley of Upper Pivka with intermittent karst lakes and flooded areas (November 2000). Floods along the Pivka river are not marked. Legend: 1. Lake and flooded areas, 2. Mean surface of Palško jezero 3. Surface stream between the lakes 4. Pivka river with tributaries 5 . Settlement 6. Kalc castle 7. Surface below $600 \mathrm{~m}$ asl 8 . Surface above 600 $\mathrm{m}$ asl.

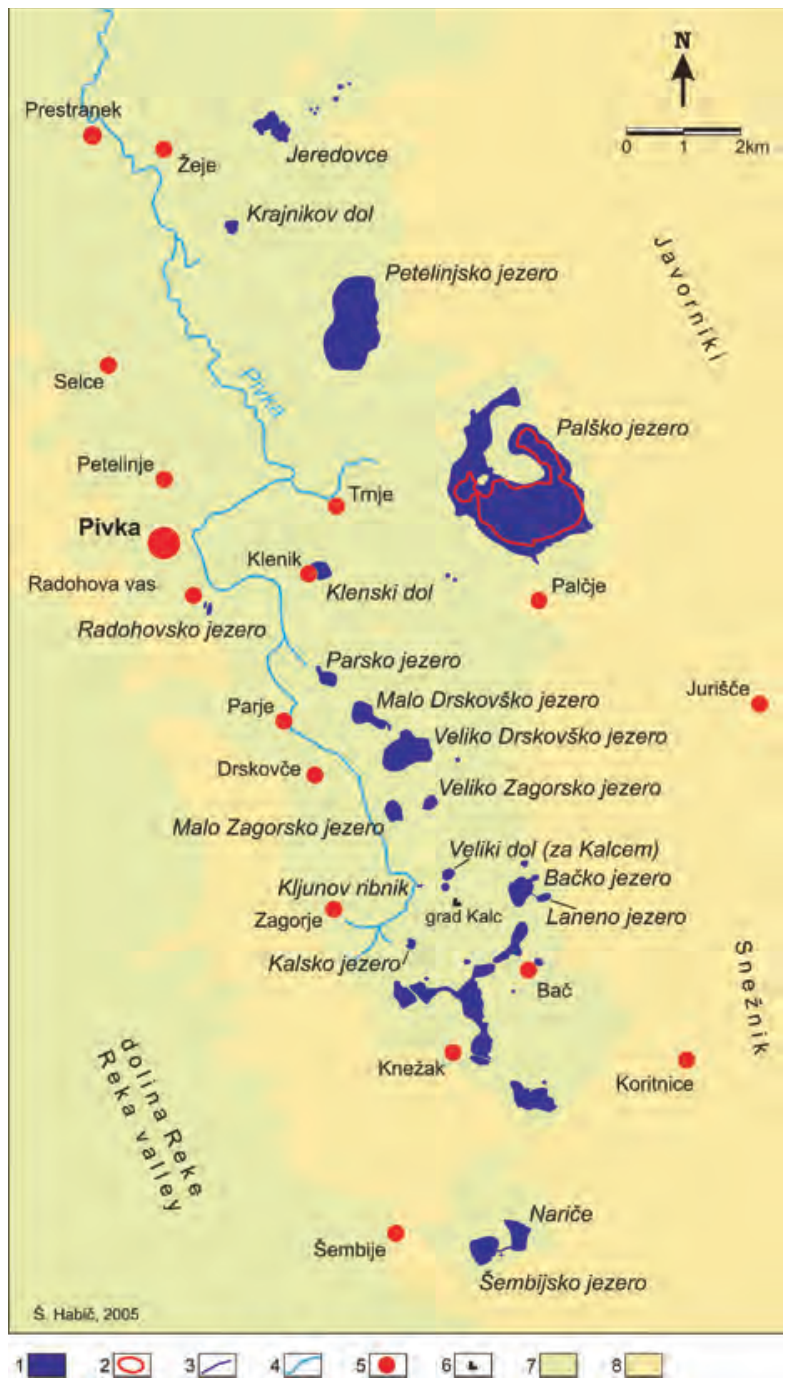


$\mathrm{V}$ primerjavi s sosednjima kraškima planotama Snežnik in Javorniki je na Zgornji Pivki izoblikovan relativno plitek kraški vodonosnik. Eden izmed vzrokov je zagotovo prisotnost spodaj ležečih flišnih kamnin, ki se zadržujejo dokaj blizu površja. V tektonskem smislu je eocenski fliš del prevrnjene gube Komenske narivne grude, ki leži pod narivom Snežniške narivne grude, zgrajene večinoma iz zgornjekrednih apnencev (Placer 1981). Flišna zapora, ki je nastala pri gubanju in narivanju, preprečuje podzemni odtok kraške vode v smeri reke Reke. Zato Pivka, ki zbira svojo vodo tudi iz globoko zakrasele Snežniške planote, izvira pri Zagorju (Pleničar 1959).

Na Zgornji Pivki se globina podtalnice giblje med 560 m n.v. v južnem delu doline $\mathrm{v}$ okolici Knežaka (Krivic et al. 1983) in $516 \mathrm{~m}$ n.v. v Matijevi jami na Palškem jezeru (Habič 1968b). Matijeva jama je značilna estavela $\mathrm{z}$ izrazitim nihanjem vodostajev (40 $\mathrm{m}$ in več). Ob visokih vodah novembra 2000 se je voda $\mathrm{v}$ jami dvignila za dodatnih $8 \mathrm{~m}$ nad do sedaj najvišje izmerjenim vodostajem in je dosegla višino $566 \mathrm{~m}$.

Eden izmed vzrokov za pojavljanje kraških presihajočih jezer na Zgornji Pivki je tudi omejena prepustnost vodnih kanalov v smeri kraškega izvira Malni (Planinsko polje) (Habič 1968b), kar v deževnih obdobjih povzroča poplave vzdolž struge Pivke ter obenem poplave $\mathrm{v}$ manjših kraških globelih, ki se takrat spremene v jezera. Nihanje vodostajev v jezerih, ki ležijo bližje reki Pivki, je manjše kot v od nje bolj oddaljenih jezerih (Habič 1985). $\mathrm{V}$ osnovi je zapolnitev jezer posledica dejstva, da je napajanje v območju izrazitejše od odtoka. $\mathrm{V}$ splošnem je na Zgornji Pivki izoblikovan bolj ali manj enoten plitek kraški vodonosnik, vendar pa lahko na podlagi podatkov o nihanju vodostajev v različnih jezerih sklepamo, da je prepustnost $\mathrm{v}$ vodonosniku zelo različna.
In contrast to the surrounding karst plateaus of Snežnik and Javorniki, the Upper Pivka valley forms a relatively shallow karst aquifer. One of the reasons is probably the presence of underlying flysch rocks, which lie close to the surface. Tectonically the Eocene flysch rocks belong to the recumbent fold of the Komen thrust sheet, which lies under the overthrust of the Snežnik thrust sheet, built up mostly of Upper Cretaceous limestones (Placer 1981). The flysch barrier, caused by folding and thrusting, prevents the underground runoff of karst water towards the Reka river. For that reason the Pivka river originates near Zagorje (Pleničar 1959), gathering its water also from the deeply karstified Snežnik plateau.

The height of the water table in the Upper Pivka aquifer ranges from $560 \mathrm{~m}$ asl on the southern part of the valley (the area around Knežak) (Krivic et al. 1983) to $516 \mathrm{~m}$ asl in the Matijeva jama cave, situated at Palško jezero (Habič 1968b). Matijeva jama is a typical estavelle with considerable oscillations of water level (40 $\mathrm{m}$ and more). During the high waters in November 2000 water rose for additional $8 \mathrm{~m}$ above the maximum height recorded previously, reaching $566 \mathrm{~m}$.

Another reason for the appearance of the lakes in Upper Pivka is the limited permeability of the water channels towards the Malni springs (Planinsko polje) (Habič 1968b), causing flooding around the Pivka riverbed in wet seasons and at the same time floods in small karst depressions which become lakes. The fluctuation of the water levels in the lakes situated closer to the Pivka riverbed is smaller than in the lakes situated farther from it (Habič 1985). The overflowing in the lakes is basically the consequence of the fact that underground recharging is stronger then subsurface runoff from the region. In general the Upper Pivka forms a more or less uniform shallow aquifer, but according to the data about the oscillations of water levels in different lakes, the permeability in the aquifer varies significantly. 


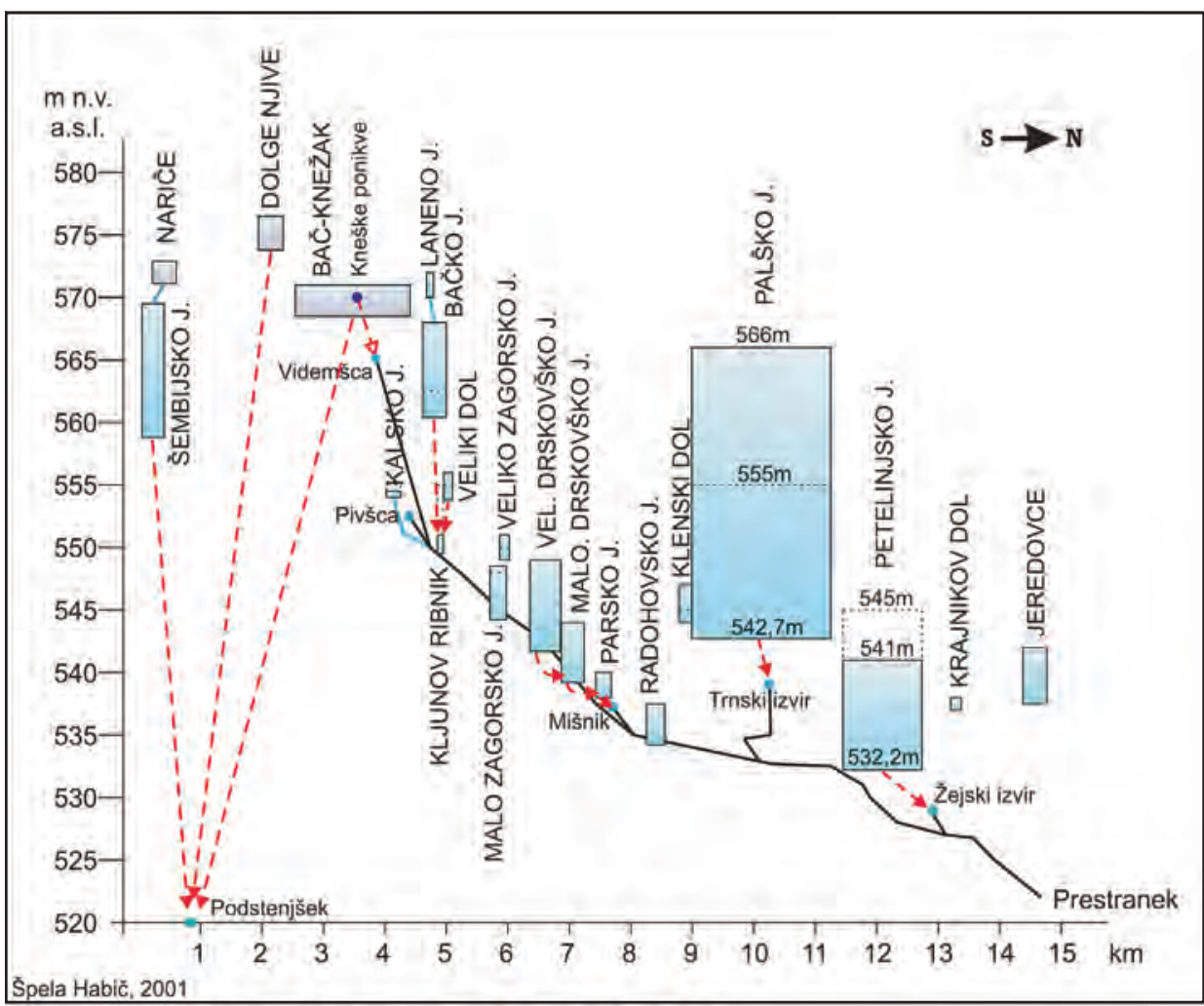

$1 \square \quad 2 \square \quad 3 \square \quad 4 \square \quad 5 \square \quad 6 \square \quad 7 \square \quad 8$

Slika 2: Profil Pivke in presihajočih jezer v novembru 2000. Legenda: 1. jezero 2. poplavljeno območje 3 . srednji vodostaj jezera 4. struga Pivke 5. površinski tok 6. podzemni tok 7. kraški izvir 8 . ponor

$\mathrm{Na}$ Zgornji Pivki je gladina podtalnice v splošnem nagnjena proti severu, z izjemo hidrološkega zaledja Šembijskega jezera, kjer visi proti severozahodu. Voda iz Šembijskega jezera napaja kraški izvir Podstenjšek, ki je desni pritok reke Reke (jadransko povodje), medtem ko je reka Pivka $z$ ostalimi šestnajstimi jezeri del hidrografskega zaledja Ljubljanice (črnomorsko povodje). Ta predel Zgornje Pivke tako predstavlja razvodje med jadranskim in črnomorskim povodjem. Kljub dejstvu, da je Šembijsko jezero v ozkem hidrološkem
Figure 2: The profile of Pivka riverbed and the intermittent lakes in November 2000. Legend: 1. Lake 2. Flooded area 3. Mean water level of the lake 4. Pivka riverbed 5. Surface stream 6. Underground water flow 7. Karst spring 8. Ponor

The water table of the Upper Pivka karst aquifer is generally inclined northwards, with the exception of the hydrological background of Šembijsko jezero, where it is inclined to the northwest. The water from Šembijsko jezero recharges the Podstenjšek karst spring which is a right tributary of the Reka river (Adriatic Sea basin) while the Pivka river with associated intermittent lakes is a part of the recharge area of the Ljubljanica river (Black Sea basin). Therefore the southern part of the Upper Pivka presents a watershed between the Adriatic and 
pogledu očitno del jadranskega povodja, ga glede na geologijo in druge naravne značilnosti obravnavamo skupaj z ostalimi presihajočimi Pivškimi jezeri.

Z izjemo Palškega in Malega Drskovškega jezera, se vsa jezera napajajo in praznijo pretežno skozi aluvialne naplavine, ki prekrivajo njihova zakrasela dna. Prvi dve se dodatno napajata in praznita skozi manjše izvorne in ponorne jame. Plasti aluvialnih naplavin skoraj gotovo prispevajo $\mathrm{k}$ trajanju ojezeritve posameznih kotanj.

\section{OBILNE PADAVINE IN VISOKE VODE NOVEMBRA 2000}

$\mathrm{V}$ jeseni 2000, posebno $\mathrm{V}$ oktobru in novembru, je nad zahodno in srednjo Evropo prevladovalogloboko območjenizkega zračnega pritiska. Ves mesec november so si v zelo kratkih razmikih sledile hladne fronte, katerih posledica je bilo obilno deževje predvsem na zahodu Slovenije. Posledica advekcije vlažnih in toplih zračnih mas so bile lokalno obilne in dolgotrajne padavine. Ponekod je oktobra in novembra padlo tudi do štirikrat več padavin, kot je povprečna količina za omenjena meseca (Dolinar 2000/2001; Markošek \& Polajnar 2000/2001).

Podatki o padavinah $\mathrm{z}$ referenčnih meteoroloških postaj Postojna, Ilirska Bistrica in Jurišče za september, oktober in november 2000 (Podatki ARSO) kažejo, da je bila na Pivškem povprečna količina padavin za vse tri mesece skupaj (obdobje 1961-1990) skoraj dvakrat presežena. Obilne padavine so dosegle višek v novembru, ko je bilo na meteoroloških postajah Postojna in Jurišče zabeleženih samo sedem dni brez dežja in dan manj na meteorološki postaji Ilirska Bistrica. Prvo neprekinjeno obdobje s padavinami je bilo po podatkih z meteoroloških postaj Postojna, Ilirska Bistrica in Jurišče zabeleženo med 30. oktobrom in 11. novembrom $(230.1,275.8$, $332.6 \mathrm{~mm}$ ), drugo med 13. in 22. novembrom
Black seas. Because of the geology and other natural characteristics, Šembijsko jezero is discussed together with the other intermittent lakes of Pivka, but from the narrower hydrological view it obviously belongs to the Adriatic Sea basin.

With the exception of Palško jezero and Malo Drskovško jezero, all the other lakes recharge and discharge mainly through the alluvial sediments which cover their karstified bottoms. The previous two are additionally recharged and discharged also from the small spring or ponor caves. Layers of alluvial deposits almost certainly contribute to the flood duration of the lakes.

\section{HEAVY PRECIPITATION AND HIGH WATERS IN NOVEMBER 2000}

In the autumn of 2000, especially in October and November, a deep low over Western and Middle Europe prevailed. During November cold fronts were following at short intervals, causing abundant precipitation especially in the western part of Slovenia. Due to the advection of moist and warm air, heavy local precipitation was of long duration. In some places the monthly amounts of precipitation in October and November were four times the average (Dolinar 2000/2001; Markošek \& Polajnar 2000/2001).

The amount of precipitation in September, October and November 2000 at the reference meteorological stations Postojna, Ilirska Bistrica and Jurišče (data by the Environmental Agency of the Republic of Slovenia) show, that in the region of Pivka the precipitation for all three months together was nearly two times the average in the period 1961-1990. Heavy precipitation reached its maximum in November when only 7 days without rain were recorded at the meteorological stations Postojna and Jurišče and six at the meteorological station Ilirska Bistrica. The first continuous period of rainfall was, according to the data from the reference 
$(163,191.2,217.5 \mathrm{~mm})$ in tretje med 24. in 26. novembrom $(63.5,77,53.7 \mathrm{~mm})$. V novembru 2000 je količina padavin na Pivškem trikrat presegla povprečno količino padavin za obdobje 1961-1990 (Postojna 455.2 mm, Ilirska Bistrica $544 \mathrm{~mm}$, Jurišče $601.6 \mathrm{~mm}$ ), kar se je odrazilo v izrazitem dvigu nivoja podtalnice. meteorological stations Postojna, Ilirska Bistirca and Jurišče, recorded from October 30 to November $11(230.1,275.8,332.6 \mathrm{~mm})$, the second from November 13 to $22(163,191.2$, $217.5 \mathrm{~mm}$ ) and the third from November 24 to $26(63.5,77,53.7 \mathrm{~mm})$. In November 2000, the amount of precipitation in the region of Pivka was three times the average monthly amount for the period 1961-1990 (Postojna $455.2 \mathrm{~mm}$, Ilirska Bistrica $544 \mathrm{~mm}$, Jurišče $601.6 \mathrm{~mm}$ ), which resulted in the intense rising of the water table.

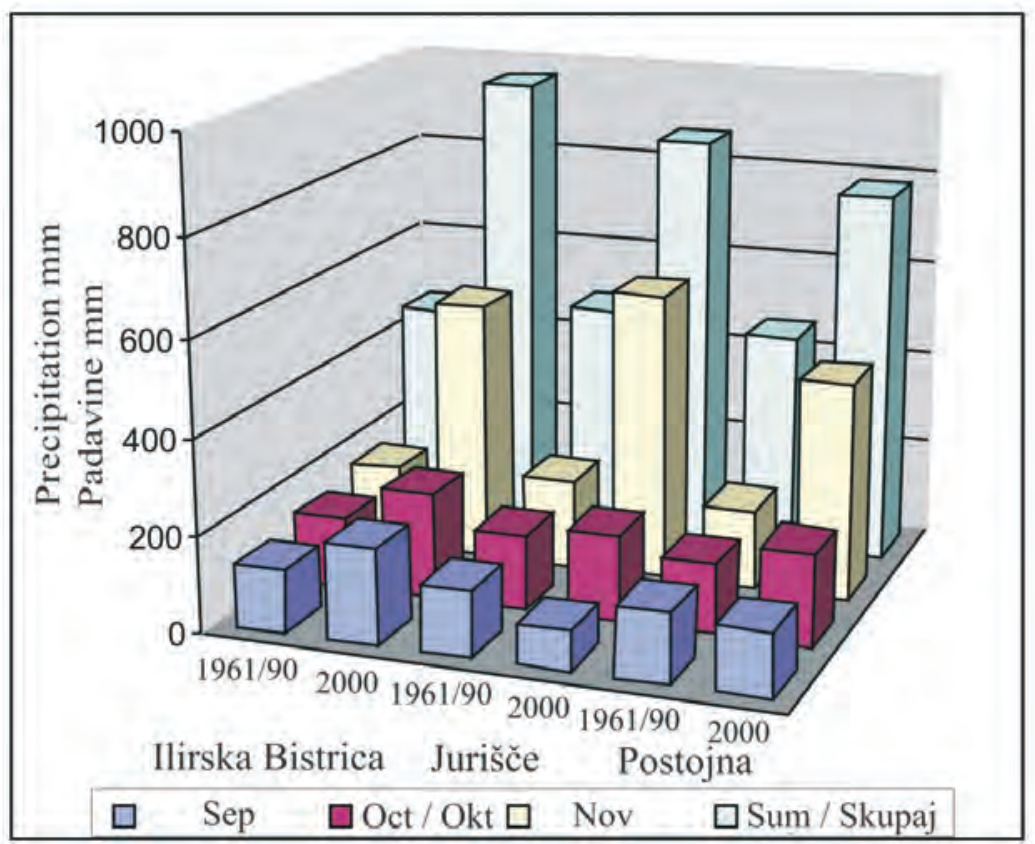

Slika 3: Podatki o padavinah na meteoroloških postajah Ilirska Bistrica, Jurišče in Postojna v obdobju od septembra do novembra 2000 in povprečne količine za obdobje 1961-1990 (Markošek \& Polajnar 2000/2001; Zupančič 1995)

Vodnatost stalnih kraških izvirov se je hitro povečala, oživeli so tudi številni pobočni kraški izviri, kar je povzročilo obsežne poplave ob toku Pivke. Dvig podtalnice se je odrazil z zalitjem 17 presihajočih jezer, izjemoma pa
Figure 3: Precipitation at meteorological stations Ilirska Bistrica, Jurišče and Postojna between September and November 2000 and the mean monthly precipitation in the period 1961-1990 (Markošek \& Polajnar 2000/2001; Zupančič 1995)

The discharges of permanent karst springs rapidly increased; in addition karst springs also emerged at higher elevations, causing extensive flooding around the Pivka riverbed. The rise of groundwater table resulted in the filling of 
so bile poplavljene tudi nekatere višje ležeče kraške kotanje. Gladina vode se je v dveh presihajočih jezerih dvignila za okoli $10 \mathrm{~m}$ nad srednji vodostaj (Palško jezero, Šembijsko jezero), približno tolikšen je moral biti tudi dvig gladine podtalnice $\mathrm{v}$ kraškem vodonosniku. Tako visoki vodostaji so se pojavili po približno sedemdesetih letih. Vendar pa obstajajo očitne razlike $\mathrm{v}$ dvigu vodostajev med posameznimi jezeri. Eden izmed poglavitnejših vzrokov je najverjetneje tudi stopnja razvitosti podzemnih vodnih kanalov. Nekatere izmed poplavljenih kraških kotanj imajo verjetno bolje razvite podzemeljske povezave kot ostale, kar povzroča razlike $\mathrm{v}$ nihanju nivoja podtalnice znotraj območja. To se je odrazilo $\mathrm{v}$ hitri zapolnitvi nekaterih jezer, ki so tako dosegla rekordne vodostaje, medtem ko so vodostaji posameznih jezer komaj dosegli srednje vrednosti. Izrazitejše nihanje vodostajev je bilo zabeleženo v jezerih, ki so bolj oddaljena od reke Pivke. $\mathrm{Na}$ poplavnem območju v okolici Knežaka in Bača ter v okolici Šembijskega jezera se je tako nivo podtalnice dvignil za približno $30 \mathrm{~m}$ in več nad srednji nivo. Rekordni vodostaji so bili zabeleženi tudi v nekaterih drugih jezerih, še posebno na Palškem jezeru, kjer se je v tistem obdobju stranski vhod v Matijevo jamo nahajal skoraj $20 \mathrm{~m}$ pod gladino jezera.

Pritisk podtalnice, ki je silila na površje iz kraškega vodonosnika, je bil izjemno velik in voda je na območju jezer vrela na dan v številnih drobnih izvirkih. Na posameznih območjih, kjer je bila travna ruša pregosta, se je pod njo naredila svojevrstna vodna blazina. Ob pritisku na napeto površino se je »blazina« upognila, predrla pa se ni. Pojav je bil opazovan v okolici Šembijskega in Palškega jezera. the 17 intermittent lakes; exceptionally some other karst depressions at higher elevations were also flooded. The water levels in the two of the regularly flooded lakes (Palško jezero, Šembijsko jezero) rose by about $10 \mathrm{~m}$ above the mean values, showing that the water table in the karst aquifer rose by about the same value. Such a high water table has not been seen for about 70 years. However, obvious differences in water level rising occurred between the lakes. One major reason is apparently the stage of the development of the underground water channels. Some of the flooded karst depressions have probably stronger underground water connections than others, causing the differences in fluctuations of groundwater level inside the area. Thus some of the lakes were flooded more rapidly than others and reached record values, while on the other hand some lakes hardly reached the mean water levels. It was observed that the changes of water levels were greater in the lakes situated farther from the Pivka river. In the flooding area around the settlements of Knežak and Bač and in the area of Šembijsko jezero the water table rose about $30 \mathrm{~m}$ and more above its mean values. Record heights of water levels were also recorded in other lakes, especially in Palško jezero, where the side entrance to the Matijeva jama cave was almost $20 \mathrm{~m}$ below the lake surface at that time.

The pressure of the underground water emerging at the surface from the karst aquifer was very high and the water was flowing from numerous small springs. At some locations, where the turf was more compact, some kind of "natural" waterbed formed beneath it. As a result of man's pressure on such curved surface, the turf moved, but did not break. This phenomenon was observed in the area of Šembijsko jezero and Palško jezero. 


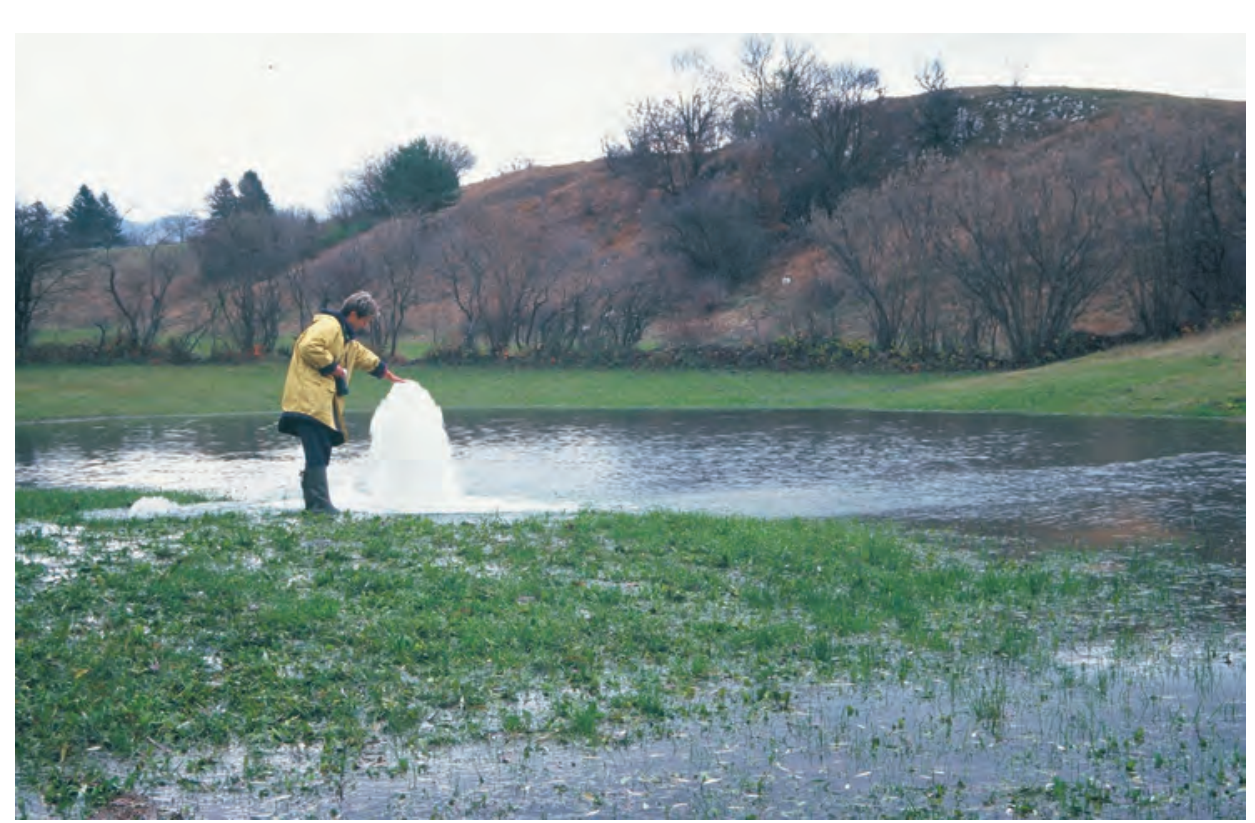

Slika 4: Bruhanje kraške podtalnice iz vrtine v Figure 4: Karst groundwater erupting from a borehole

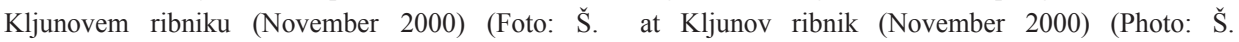
Habič)

Habič)

\section{KRAŠKA PRESIHAJOČA JEZERA OB VI- INTERMITTENT KARST LAKES DUR- SOKIH VODAH NOVEMBRA 2000 ING HIGH WATERS IN NOVEMBER 2000}

Tabela 1: Osnovne značilnosti Pivških presihajočih

Table 1: Basic characteristics of the Pivka periodical jezer. lakes.

\begin{tabular}{|c|c|c|c|c|c|c|c|}
\hline \multirow{2}{*}{$\begin{array}{c}\text { Ime jezera } \\
\text { Name of the lake }\end{array}$} & \multirow{2}{*}{\begin{tabular}{|c|} 
Dno \\
jezera v m \\
n.v. \\
Lake \\
bottom \\
in \\
m asl
\end{tabular}} & \multicolumn{2}{|c|}{$\begin{array}{l}\text { Vodostaj jezera } \mathrm{V} \mathrm{m} \\
\text { n.v. } \\
\text { Water level of the lake } \\
\text { in } \mathrm{m} \text { asl }\end{array}$} & \multicolumn{2}{|c|}{$\begin{array}{l}\text { Površina jezera } \mathrm{v} \mathrm{m}^{2} \\
\text { Surface of the lake } \\
\text { in } \mathrm{m}^{2}\end{array}$} & \multicolumn{2}{|c|}{$\begin{array}{c}\text { Prostornina jezera } \mathrm{v} \mathrm{m}^{3} \\
\text { Volume of the lake } \\
\text { in } \mathrm{m}^{3}\end{array}$} \\
\hline & & $\begin{array}{l}\text { Srednji } \\
\text { Mean }\end{array}$ & $11 / 2000$ & $\begin{array}{l}\text { Srednji } \\
\text { Mean }\end{array}$ & $11 / 2000$ & $\begin{array}{c}\text { Srednji } \\
\text { Mean }\end{array}$ & $11 / 2000$ \\
\hline $\begin{array}{l}\text { 1. Šembijsko } \\
\text { jezero }\end{array}$ & 558.8 & 560 & 569.5 & 12381 & 93561 & 11274 & 549971 \\
\hline 1.a. Nariče & 571.1 & 0 & 573 & $*$ & 78092 & $*$ & 82966 \\
\hline \begin{tabular}{|l|} 
2. Poplavno \\
območje okoli \\
Knežaka in \\
Bača
\end{tabular} & 568.5 & 0 & $\begin{array}{c}571- \\
576.5\end{array}$ & * & 591419 & $*$ & 591417 \\
\hline
\end{tabular}




\begin{tabular}{|c|c|c|c|c|c|c|c|}
\hline \multirow{2}{*}{$\begin{array}{c}\text { Ime jezera } \\
\text { Name of the lake }\end{array}$} & \multirow{2}{*}{\begin{tabular}{|c} 
Dno \\
jezera v m \\
n.v. \\
Lake \\
bottom \\
in \\
m asl
\end{tabular}} & \multicolumn{2}{|c|}{$\begin{array}{l}\text { Vodostaj jezera v m } \\
\text { n.v. } \\
\text { Water level of the lake } \\
\text { in m asl }\end{array}$} & \multicolumn{2}{|c|}{$\begin{array}{l}\text { Površina jezera } \mathrm{v} \mathrm{m}^{2} \\
\text { Surface of the lake } \\
\text { in } \mathrm{m}^{2}\end{array}$} & \multicolumn{2}{|c|}{$\begin{array}{c}\text { Prostornina jezera } \mathrm{v} \mathrm{m}^{3} \\
\text { Volume of the lake } \\
\text { in } \mathrm{m}^{3}\end{array}$} \\
\hline & & $\begin{array}{l}\text { Srednji } \\
\text { Mean }\end{array}$ & $11 / 2000$ & $\begin{array}{l}\text { Srednji } \\
\text { Mean }\end{array}$ & $11 / 2000$ & $\begin{array}{l}\text { Srednji } \\
\text { Mean }\end{array}$ & $11 / 2000$ \\
\hline 3. Kalsko jezero & 553.8 & 555 & 554.5 & 56368 & 16280 & 26813 & 6937 \\
\hline 4. Laneno jezero & 570.2 & $*$ & 572 & $*$ & 12384 & $*$ & 19308 \\
\hline 5. Bačko jezero & 560.4 & 562.5 & 568 & 32531 & 86250 & 64,648 & 392551 \\
\hline 6. Kljunov ribnik & 549.5 & 551 & 551 & 784 & 784 & 80 & 80 \\
\hline $\begin{array}{l}\text { 7. Veliki dol (za } \\
\text { Kalcem) }\end{array}$ & 553.8 & 555 & 556 & 15001 & 18496 & 26729 & 42125 \\
\hline \begin{tabular}{|l|} 
8. Veliko \\
Zagorsko \\
jezero
\end{tabular} & 549 & 550 & 551 & 16552 & 23479 & 19920 & 39085 \\
\hline $\begin{array}{l}\text { 9. Malo Zagorsko } \\
\text { jezero }\end{array}$ & 544.2 & 548 & 548.5 & 39425 & 44552 & 83100 & 103768 \\
\hline \begin{tabular}{|l} 
10. Veliko \\
Drskovško \\
jezero
\end{tabular} & 541.7 & 545 & 549 & 186334 & 207547 & 441427 & 1247611 \\
\hline \begin{tabular}{|l|} 
11. Malo \\
Drskovško \\
jezero
\end{tabular} & 539.2 & 540 & 544 & 41120 & 82657 & 52593 & 327782 \\
\hline 12. Parsko jezero & 538 & 540 & 542 & 29798 & 37231 & 46060 & 114594 \\
\hline $\begin{array}{l}\text { 13. Radohovsko } \\
\text { jezero }\end{array}$ & 534.2 & 536 & 535.6 & 15519 & 7455 & 22434 & 14221 \\
\hline 14. Klenski dol & 544 & 545 & 547.5 & 3689 & 36830 & 1330 & 57565 \\
\hline 15. Palško jezero & 542.3 & 555 & 566 & 1027812 & 1904784 & 7144854 & 22983817 \\
\hline $\begin{array}{l}\text { 16. Petelinjsko } \\
\text { jezero }\end{array}$ & 532.2 & 545 & 541 & 736341 & 647157 & 6891976 & 4128712 \\
\hline 17. Krajnikov dol & 537 & $*$ & 540 & $*$ & 21513 & $*$ & 18849 \\
\hline 18. Jeredovce & 537.5 & * & 542 & $*$ & 90197 & $*$ & 113428 \\
\hline
\end{tabular}

* Ni podatka.

o Poplava je redek pojav.

1) Srednji vodostaji jezer so odčitani s temeljnih topografskih načrtov v merilu 1:5000, vodostaji novembra 2000 so bili izmerjeni na terenu.

2) Površine in prostornine jezer so bile izračunane $s$ pomočjo Golden Software Diger in Surface programskega paketa.
*No data available.

o Flooding is very rare.

1) Mean water levels of the lakes were read from the basic topographic maps at the scale 1:5000; water levels in November 2000 were measured on the field. 2) Surfaces and volumes of the lakes were calculated using the Golden Software Didger and Surface program tools. 


\section{ŠEMBIJSKO JEZERO}

Šembijsko jezero leži najbolj južno izmed vseh jezer na Zgornji Pivki. Nedaleč od jezera se kraški svet Zgornje Pivke namreč skokovito spusti v dolino reke Reke. Nad Šembijskim jezerom se dviga Jezerni hrib (598 m), ki z imenom priča o zanimivem kraškem pojavu tudi tedaj, ko je zaraščajoča se travnata planota povsem osušena.

$\mathrm{Z}$ dnom na nadmorski višini $558,8 \mathrm{~m}$ Šembijsko jezero ni najvišje ležeče, prekašata ga Laneno in Bačko jezero. Tudi ozemlje v okolici Knežaka, ki je bilo v letu 2000 poplavljeno, leži približno $10 \mathrm{~m}$ višje. Jezero se polni s podzemno vodo iz prostranega zaledja Snežniške planote in pod površjem odteka v izvir Podstenjšek in naprej proti Jadranskemu morju. Ob obilnih padavinah v novembru 2000 je vodna gladina $\mathrm{v}$ jezeru izjemno narasla. Srednji vodostaj je presegla za skoraj $10 \mathrm{~m}$ in dosegla $569,5 \mathrm{~m}$ n.v. Takrat je voda v izviru Podstenjšek izvirala iz jame Kozja luknja, ki leži približno $30 \mathrm{~m}$ višje od stalnega izvira, na nadmorski višini $575 \mathrm{~m}$.

V neposredni bližini Šembijskega jezera leži velika, plitva kotanja Nariče z uravnanim dnom na $571 \mathrm{~m}$. Novembra 2000 je bila poplavljena. Po spominu domačinov se je to nazadnje zgodilo leta 1929. Ob najvišjem vodostaju $(572,9 \mathrm{~m})$ se je voda iz Narič več dni površinsko pretakala v Šembijsko jezero. Potok je bil širok nekaj metrov, le v spodnjem delu se je zožil. V tem času se je voda pojavila tudi $\mathrm{v}$ majhni vrtači nekaj metrov južneje od potoka.

\section{POPLAVNO OBMOČJE OKOLI KNEŽAKA IN BAČA}

Novembra 2000 je bil dvig gladine kraške vode najbolj izrazit $\mathrm{v}$ okolici Knežaka in Bača, kjer je prišlo do obsežnih poplav. Vodna gladina je segla najvišje na območju Dolgih njiv, jugovzhodno od Knežaka, in sicer do 576,5 $\mathrm{m}$ n.v. Poplavna površina $\mathrm{v}$ okolici Knežaka ni bila sklenjena in vodostaji posameznih

\section{ŠEMBIJSKO JEZERO}

Šembijsko jezero is the southernmost lake in Upper Pivka. Westwards from the lake, not far away, the karstified region of Upper Pivka borders on the flysch region of the Reka valley. The name of a small hill above the lake (Jezerni hrib - "Lake Hill", $598 \mathrm{~m}$ asl) gives evidence of this interesting karst phenomenon also when the nearby overgrown pastures are completely dry.

With its bottom at an elevation of 558.8 $\mathrm{m}$ asl, Šembijsko jezero is not the highest lake of all; the Laneno and Bačko jezero lakes are situated at higher elevations. The flooding area around the villages Knežak and Bač also lies about $10 \mathrm{~m}$ higher. The lake gathers its water from the vast and deeply karstified Snežnik plateau. The water from the lake outflows through the Podstenjšek karst spring and further to the Adriatic Sea. In November 2000, the water level of Šembijsko jezero exceeded its mean value by $10 \mathrm{~m}$ and reached an elevation of $569.5 \mathrm{~m}$ asl. At that time, the water of the Podstenjšek spring originated from the Kozja jama cave, at $575 \mathrm{~m}$ asl, which lies around $30 \mathrm{~m}$ above the permanent spring.

Adjacent to Šembijsko jezero lies a shallow depression, named Nariče, with its bottom at $571 \mathrm{~m}$ asl, which was also flooded for the first time since 1929, according to local people. When the water table was at its highest level ( $572.9 \mathrm{~m}$ asl), its water was pouring as a several metre wide surface flow into the lake. The water also appeared in a small doline to the south of the surface stream.

\section{THE FLOODING AREA AROUND KNEŽAK AND BAČ}

In November 2000, the water table rise was highest in the surroundings of the settlements Knežak and Bač, where extensive flooding occurred. The water reached its highest level in the area of Dolge njive (576.5 m asl), southeast from Knežak. The entire flooded 
zaključenih poplavnih območij so dosegli različne nadmorske višine (571 do $576,5 \mathrm{~m}$ ). Poplavljeno območje s skupno površino 591000 $\mathrm{m}^{2}$ se je raztezalo $\mathrm{v}$ treh izrazitih krakih na uleknjenem površju med Knežakom in Bačem. Jugovzhodni krak je poplavil Jermance, Zelnike in Pod Obrobo, pri čemer cesta KnežakKoritnice ni bila poplavljena. Severovzhodni krak je zalil območja Pod Pezalco, Robidnice, Podjame, deloma Dolenji Kraj ter Zelnike in Kot severno od Bača. Cesta med Knežakom in Bačem je bila zalita in neprevozna več dni na dolžini dobrih $50 \mathrm{~m}$. Ločeno se je voda pojavila še v plitvi kotanji med Rebrnikom in Koncami. Tretji, severozahodni krak, je z območja Robidnice v ozkem pasu segel proti Ozkim njivam, Zapotoku in Ponikvam. Poplavljeno območje Ozkih njiv je od Zapotoka in Ponikev ločeval umetno izravnan in med nasipa ujeti jarek potoka, ki s flišnega tektonskega okna zahodno od Knežaka odteka v ponor Ponikve in podzemno v izvir Videmščice pri Zagorju ter dalje v Pivko. Nekaj dni v novembru je voda poplavila tudi predel Bača, imenovan Rep, kjer je zalilo kleti v bližnjih hišah. Poplavilo je tudi Gorenji Kraj naselja Bač in prostore tovarne Javor na vzhodnem delu naselja. $\mathrm{V}$ tem delu je voda ob viških segala tudi do $580 \mathrm{~m} \mathrm{n.v,} \mathrm{k}$ poplavljanju naselja Bač pa je poleg kraške podtalnice pripomogel tudi površinski vodotok, ki je iz suhe struge nekdanje Pivke po cesti pritekal neposredno v naselje.

\section{BAČKO IN LANENO JEZERO}

Severno od Bača leži skupina štirih globeli. Čeprav se po velikosti med seboj opazno razlikujejo, jim je skupen strmejši jugovzhodni del oboda - to lahko opazujemo tudi pri mnogih drugih jezerih. V največji globeli, z dnom na $560 \mathrm{~m}$ n.v., v letih z obilnimi padavinami nastaja Bačko jezero. Njegova globina običajno ne preseže dveh metrov. Ostale tri manjše globeli ležijo vzhodno od Bačkega jezera, v ravni liniji JV-SZ in z nadmorskimi višinami dna na 570,2 $\mathrm{m}, 567,3 \mathrm{~m}$ in $565,9 \mathrm{~m}$. V novembru 2000 so bile vse tri globeli poplavljene. Domačini surface was not enclosed and the water level of some individual flooded areas reached different elevations (between $571 \mathrm{~m}$ asl and $576.5 \mathrm{~m}$ asl), although these areas lay very close to one another. The total flooded area near Knežak and Bač was more than $591000 \mathrm{~m}^{2}$ and extended in three branches. The shallow depressions named Jermance, Zelniki and Pod Obrobo respectively were filled with the water from the southeastern branch, but the road connecting Knežak and Koritnice remained above the water surface. The northeastern branch flooded Robidnice, Podjame, Pod Pezalco, partly Dolenji Kraj, Zelniki and Kot to the north of Bač. The road between Knežak and Bač was flooded for several days for a length of $50 \mathrm{~m}$. The northwestern branch extended towards Ozke njive, Zapotok and Ponikve. The areas of Zapotok and Ponikve were separated from Ozke njive by an artificial ditch, which draws off a stream originating from a flysch tectonic window lying westwards from Knežak. At the end of the ditch the stream sinks into the ponor Ponikve and springs out in the Videmščica spring, a tributary of the Pivka. Some flooding also occurred in the area of Bač named Rep, where some cellars of nearby houses were flooded. Flood damage was also reported in the eastern parts of Bač, where the water level at its peaks reached an elevation of 580 $\mathrm{m}$ asl. Besides the karst groundwater, a surface stream flowing along the local road directly to the village from the former dry bed of the Pivka also contributed to the flooding of Bač.

\section{BAČKO JEZERO AND LANENO JEZERO}

To the north of Bač lies a group of four karst depressions. Although they are of markedly different size, they have one characteristic in common: a steep southeastern slope, which also exsist in many other depressions in Upper Pivka. In the largest of the four depressions (with its bottom at an elevation of $560 \mathrm{~m}$ asl), a lake called Bačko jezero occurs after periods of heavy precipitation. Its depth usually does not exceed $2 \mathrm{~m}$. The other three depressions, which are smaller, lie eastwards from the lake 
pripovedujejo, da so v dolini, ki je vasi najbližja, nekoč gojili lan, zato jo imenujejo Laneno jezero. To je najvišje ležeče jezero na Zgornji Pivki, zato je razumljivo, da je le izjemoma poplavljeno. Voda je leta 2000 segla do $572 \mathrm{~m}$ n.v. in se je po površju prelivala $\mathrm{v}$ sto metrov oddaljeno Bačko jezero, kjer se je gladina dvignila na $568 \mathrm{~m}$. Ob tem je zalilo še drugo manjšo vrtačo na njegovem severovzhodnem robu in nastalo je jezero $\mathrm{z}$ enotno gladino. Prostornina (392551 $\mathrm{m}^{3}$ ) je tedaj kar za šestkrat presegla prostornino Bačkega jezera ob srednjem vodostaju. Severno od Bačkega jezera je voda zapolnila vrtačo in nastalo je manjše jezerce $\left(4423 \mathrm{~m}^{2}\right) \mathrm{z}$ gladino vode na nadmorski višini $569,5 \mathrm{~m}$ in s prostornino $23631 \mathrm{~m}^{3}$.

\section{KALSKO JEZERO, VELIKI DOL (ZA KALCEM) IN KLJUNOV RIBNIK}

Pivka izvira v Pivšcah, v odprti kraški globeli v bližini Zagorja. Ob dežju je tod več izvirov $\mathrm{v}$ nadmorski višini med 551 in 554 m. Na jugovzhodnem robu globeli so izviri Videmščice, ki podzemno dobivajo vodo iz kraškega zaledja med Zagorjem, Knežakom in Bačem. V Videmščico podzemno priteka tudi voda iz Kneških ponikev (Habič 1975). Malo pred izlitjem v Pivko doseže Videmščico umeten odvodni jarek, ki odvaja visoke vode iz bližnjega Kalskega jezera. Globel Kalskega jezera na vzhodem in južnem delu obroblja do $40 \mathrm{~m}$ visoko in dokaj strmo pobočje. $\mathrm{Na}$ uravnanem, osušenem jezerskem dnu $(553,8$ $\mathrm{m})$ prevladujejo njive in travniki. Po podatkih $\mathrm{s}$ temeljnih topografskih načrtov v merilu 1:5000 (TTN 1:5000) je srednji vodostaj Kalskega jezera na nadmorski višini $555 \mathrm{~m}$, vendar pa se zaradi sprotnega odtekanja vode po odvodnem jarku jezero pojavlja izključno $\mathrm{v}$ manjšem predelu na severni strani globeli. Domnevamo, da je podatek o srednjem vodostaju še iz časa pred izkopom jarka. Ob izjemnih vodah novembra 2000 vodna gladina ni presegla 554,5 $\mathrm{m}$, temu primerno je bila manjša tudi površina jezera. in a straight SE-NW line, with their bottoms at altitudes of $570.2 \mathrm{~m}, 567.3 \mathrm{~m}$ and $565.9 \mathrm{~m}$ respectively. In November 2000, all of them were flooded. According to local people, flax used to be grown in a doline closest to the village; hence the name of the lake which occurs in it - Laneno jezero (Flax Lake). This is the highest lake in Upper Pivka and therefore flooded only during exceptionally high waters. In November 2000 , the water level reached an elevation of $572 \mathrm{~m}$ asl and the water was pouring into Bačko jezero $100 \mathrm{~m}$ away where the water level rose to 568 $\mathrm{m}$ asl (Habič 2005). At the same time the lake flooded a nearby small doline on its northeastern edge and a single bigger lake was formed. At that time, the volume of Bačko jezero (392551 $\mathrm{m}^{3}$ ) was six times the average. Northwards from Bačko jezero, another doline was flooded and consequently a small lake was developed with its water level at $569.5 \mathrm{~m}$ asl, $4423 \mathrm{~m}^{2}$ in area and containing $23631 \mathrm{~m}^{3}$ of water.

\section{KALSKO JEZERO, VELIKI DOL (ZA KALCEM) AND KLJUNOV RIBNIK}

The Pivka river rises from the Pivšca karst spring situated in a shallow karst depression near the village of Zagorje. During high waters, several karst springs with elevations between $551 \mathrm{~m}$ and $554 \mathrm{~m}$ emerge in this area. Situated on the southeastern edge of the this depression are the Videmščica karst springs gathering water from the karst background in the vicinity of Zagorje, Knežak and Bač. Underground connections with the ponors near Knežak (Kneške ponikve) have been proved (Habič 1975). Near the confluence with the Pivka an artificial ditch, dug at the bottom of the nearby Kalsko jezero for land reclamation, reaches the Videmščica stream. The partly opened karst depression of Kalsko jezero, which lies to the southeast of Zagorje, is at its eastern and southern parts bounded with steep slopes (up to $40 \mathrm{~m}$ high). At its levelled and dry bottom (553.8 $\mathrm{m}$ asl) fields and meadows occur. According to 1:5000 scale basic topographic maps (BTM 1:5000) the mean water level of Kalsko jezero 
Severno od gradu Kalc je v majhni, redno košeni globeli z ravnim dnom Veliki dol. Dno in srednji vodostaj tega jezera sta enaka kot pri Kalskem jezeru, ker pa je bolj oddaljeno od reke Pivke, nastaja jezero veliko bolj poredko, le ob zelo visokih vodah. V novembru 2000 je vodna gladina v Velikem dolu dosegla $556 \mathrm{~m}$ n.v. Tedaj je voda napolnila tudi sosednjo plitko vrtačo do nadmorske višine $561 \mathrm{~m}$. Višinska razlika med samo 35 metrov oddaljenima vodnima površinama je torej znašala 5 m (Habič 2005). Podobno kot pri Bačkem in Lanenem jezeru tudi to dokazuje, da je bila vodna gladina $\mathrm{v}$ kraškem zaledju doline Pivke novembra 2000 izjemno visoko.

Tik preden Pivka zavije v ozko sotesko, leži na njenem desnem bregu plitva, ovalna globel, imenovana Kljunov ribnik. Pred več leti so v njegovem dnu $\mathrm{z}$ vrtanjem raziskovali nivoje podzemne kraške vode ob Pivki. Ostale so precej široke vrtine, skozi katere je v novembru in decembru 2000 voda več tednov bruhala celo več kot meter visoko (Slika 4). Narava je tu zelo nazorno predstavila izjemen pritisk podzemne vode. Ker je v severozahodnem delu Kljunov ribnik nagnjen proti reki Pivki, vodna gladina $\mathrm{V}$ njem ne more doseči $555 \mathrm{~m}$, kot je to označeno na TTN 1:5000. Do ojezeritve prihaja samo v manjšem delu kraške globeli, ki se sicer razteza še nekaj $10 \mathrm{~m}$ proti vzhodu. Novembra 2000 je iz vrtin in naravnih razpok bruhajoča voda poplavila le manjšo površino globeli do $551 \mathrm{~m}$ n.v. in je sproti po površju odtekala v Pivko.

\section{VELIKO IN MALO ZAGORSKO JEZERO}

Globel Malega Zagorskega jezera je od regulirane struge Pivke oddaljena samo 200 $\mathrm{m}$, od njene poplavne ravnice pa jo ločuje 10 $\mathrm{m}$ visoka reber. $\mathrm{V}$ južnem obrobju se globel zoži v manjši zatrep, ki je mnogo manj izrazit kot v Malem Drskovškem jezeru. Dno Malega Zagorskega jezera leži v ravnini s strugo Pivke na $544 \mathrm{~m}$ n.v., zato je pojavljanje jezera pogosto. Ob srednjem vodostaju je Malo Zagorsko jezero globoko $4 \mathrm{~m}$, novembra 2000 pa se je gladina is at $555 \mathrm{~m}$ asl. However, since the water regime of the lake changed after a ditch dug into the bottom of the lake, flooding occurs in a small section in the northern part of the depression. It is presumed that the data on the mean water level originates from a time before the ditch was dug. In November 2000, during exceptionally high waters, the water level did not exceed $554.5 \mathrm{~m}$ asl and the surface area of the lake was accordingly smaller.

To the north of Kalc Castle, in a small, regularly mown karst depression with a level bottom, lies another lake, called Veliki dol (za Kalcem). The bottom and the mean water level of this lake are of the same elevation as those of Kalsko jezero. However, since the lake lies at a greater distance from the Pivka riverbed, flooding occurs much more rarely - only during extremely high waters. In November 2000, the water level of the lake reached $556 \mathrm{~m}$ asl. At that time also a shallow doline lying $35 \mathrm{~m}$ away was flooded up to an elevation of $561 \mathrm{~m}$ asl, which means that the difference in elevation between the water level of the lake and that of the flooded doline was $5 \mathrm{~m}$ (Habič 2005). As with Bačko jezero and Laneno jezero, this phenomenon proves that in November 2000 the water table within the karst aquifer of the Pivka valley was exceptionally high.

Close to the point where the Pivka river reaches a narrow gorge, on its right bank, lies an oval shaped depression called Kljunov ribnik. During the investigations of karst groundwater table around the Pivka river many years ago, wide boreholes were dug into the bottom of the depression. In November and December 2000, water was erupting out of these boreholes for several weeks, reaching more than $1 \mathrm{~m}$ in height (Figure 4). This was Nature's clear demonstration of the strong force of groundwater pressure. Since the northwestern part of Kljunov ribnik is inclined towards the Pivka riverbed, the water level of the depression cannot rise to $555 \mathrm{~m}$ asl, as is marked on the BTM 1:5000. The lake occurs only in a small part of the depression which, however, stretches 
dvignila le za pol metra več, do 548,5 m. Na vzhodni strani globeli se ob obilnih padavinah aktivirajo manjši kraški izviri, kjer voda priteka na površje iz manjših razpok v apnencu.

Vzhodno od tod leži Veliko Zagorsko jezero. Njegovo dno je $5 \mathrm{~m}$ višje, zato jezero nastaja mnogo bolj poredko. $\mathrm{V}$ blago uleknjenem dnu doseže globina jezera običajno le en meter, površina pa je približno pol manjša kot v Malem Zagorskem jezeru. Kljub temu to jezero nosi ime »Veliko«, v njem je namreč več obdelovalne zemlje, ki je tudi manj namočena (Habič 2005). Novembra 2000 je gladina Velikega Zagorskega jezera za 1 meter presegla srednji vodostaj in je dosegla višino $551 \mathrm{~m}$.

V zaledju obeh Zagorskih jezer je v tem času voda zalila tudi plitvo globel Drenovke z dnom na 552,6 m n.v. Globina jezerca najverjetneje ni presegla enega metra, njegova površina pa je znašala $1303 \mathrm{~m}^{2}$.

\section{VELIKO IN MALO DRSKOVŠKO JEZERO}

Veliko Drskovško jezero je po velikosti tretje izmed vseh Pivških jezer $\left(186000 \mathrm{~m}^{2}\right)$. Dno njegove globeli je $\mathrm{v}$ približno isti ravnini kot struga Pivke (542 m), zato je nastajanje jezera pogosto. Čeprav je voda novembra leta 2000 kar za štiri metre presegla srednji vodostaj, površina jezera ni bila bistveno večja. Prostorno ovalno globel z naplavljenim dnom namreč obdaja dokaj strm skalnat rob. Na dnu Velikega Drskovškega jezera je več kotanj, skozi katere voda pronica v podzemlje. Na severnem obrobju se jezero podaljša $\mathrm{v}$ manjši zaliv, kjer se zelo približa Malemu Drskovškemu jezeru.

Malo Drskovško jezero je srednje od treh jezer, ki so med seboj najverjetneje povezana s podzemnim vodnim tokom (Habič 1975). Iz Velikega Drskovškega jezera voda podzemno ne odteka v strugo Pivke, temveč proti Malemu Drskovškemu jezeru. Ojezerjeni kotanji med seboj ločuje $150 \mathrm{~m}$ širok in $20 \mathrm{~m}$ visok a few tens of metres to the east. In November 2000 , the water erupting out of the boreholes and natural fissures flooded only a small area of the depression (up to an elevation of $551 \mathrm{~m}$ asl), from which it poured into the Pivka river.

\section{VELIKO ZAGORSKO JEZERO AND MALO ZAGORSKO JEZERO}

Malo Zagorsko jezero lies only $200 \mathrm{~m}$ away from the regulated Pivka river, the flooding area of which is separated from the lake by a $10 \mathrm{~m}$ high slope. On its southern margin, the lake depression narrows into a small pocket valley, which is much less pronounced than that of Malo Drskovško jezero. The bottom of Malo Zagorsko jezero lies at the same elevation as the Pivka river (544 $\mathrm{m}$ asl), so flooding occurs frequently. At mean water level the lake is $4 \mathrm{~m}$ deep; in November 2000, however, its water level rose only by $0.5 \mathrm{~m}$, to an elevation of 548.5 asl. During high waters, several small karst springs emerge from fissures in limestone rock on the eastern side of the depression.

To the east of Malo Zagorsko jezero, lies another lake, called Veliko Zagorsko jezero. Its bottom lies $5 \mathrm{~m}$ higher, which means that flooding is much less frequent. In its slightly curved bottom, the lake usually reaches a depth of $1 \mathrm{~m}$, while its surface area is approximately half the size of Malo Zagorsko jezero. Nevertheless, the lake has been named "Veliko" (Greater), however on the grounds that there is more arable land in its depression, which is also less wet (Habič 2005). In November 2000, the water level exceeded the average value by $1 \mathrm{~m}$ and reached an elevation of $551 \mathrm{~m}$ asl.

At that time, also a small doline (called Drenovke) lying in the vicinity of the two lakes and with its bottom at $552.6 \mathrm{~m}$ asl, was flooded. The depth of this small lake probably did not exceed $1 \mathrm{~m}$, while its area was $1303 \mathrm{~m}^{2}$. 
hrbet. Kotanja Malega Drskovškega jezera je nenavadna, saj zelo spominja na manjše izvirno-ponorno kraško polje. Okrogla globel jezera se namreč proti jugovzhodu potegne $\mathrm{v}$ ozko zatrepno dolino, ki se zaključuje z visoko prepadno steno. Pod njo je nekaj metrov globoka vodoravna jama, ki jo domačini imenujejo Podmou (spodmol). To je izvirna jama Malega Drskovškega jezera. Takrat voda izvira iz več manjših jamskih rovov ter grušča, ki se nahaja v podnožju zatrepne stene. Voda odteka po krajši strugi do ovalne globeli, kjer se razlije $\mathrm{v}$ jezero. Ko količina iztekajoče vode upade, voda ne doseže več širokega dela globeli, temveč ponika skozi požiralnike $\mathrm{v}$ spodnjem delu struge, približno $200 \mathrm{~m}$ pred ponorom. Večji del Malega Drskovškega jezera se prazni skozi razpoke $\mathrm{v}$ dnu, ob višjih vodostajih pa zlasti skozi ponorno jamo na severnem robu globeli. Domačini tudi to jamo poimenujejo Podmou. Medtem ko je izvirna jama zasuta predvsem s kamenjem, je ponorni Podmou dodobra napolnjen $\mathrm{z}$ drobnozrnatimi sedimenti, stene $\mathrm{V}$ njem pa so tudi deloma zasigane. Tako kot $\mathrm{v}$ Velikem Drskovškem jezeru je tudi v Malem novembra 2000 maksimalni vodostaj za štiri metre presegel srednje vrednosti, pri tem pa se je površina jezera podvojila.

\section{PARSKO JEZERO}

Parsko jezero dobiva vodo iz Malega Drskovškega jezera, katerega dno leži en meter višje. Iz Parskega jezera voda odteka v izvir Mišnik. Na omenjene podzemne zveze kažejo podatki o temperaturi in kemičnih lastnostih voda $\mathrm{v}$ naštetih jezerih in $\mathrm{v}$ Mišniku (Habič 1975). Po trajnosti in izdatnosti je Mišnik eden pomembnejših izvirov ob Pivki, kar sta nekoč s pridom izkoriščala tamkajšnja mlin in žaga. Podobno kot Veliko Drskovško jezero je tudi Parsko podaljšano z zalivom na severovzhodni strani. Novembra 2000 je globina tega jezera z običajnih dveh metrov narasla na štiri, vodna gladina je dosegla $542 \mathrm{~m}$ n.v.

\section{VELIKO DRSKOVŠKO JEZERO AND MALO DRSKOVŠKO JEZERO}

Veliko Drskovško jezero is the third largest lake in Upper Pivka $\left(186000 \mathrm{~m}^{2}\right)$. The bottom of its depression lies at about the same elevation as the Pivka river (542 $\mathrm{m}$ asl), so the depression is flooded frequently. Although in November 2000 the mean water level was exceeded by 4 $\mathrm{m}$, the surface area of the lake did not increase significantly. The reason for this was that the oval-shaped depression with its flooded bottom is bounded along its edges by a rather steep rocky slope. The water of the lake sinks through several small ponors at its bottom. On its northern side the lake extends into a small bay, where it approaches close to Malo Drskovško jezero.

Malo Drskovško jezero is the second in the line of three lakes, which are most probably interconnected by an underground flow (Habič 1975). The sinking water of Veliko Drskovško jezero does not flow towards the Pivka riverbed, but reappears in Malo Drskovško jezero. The depressions of the two lakes are separated by a $150 \mathrm{~m}$ wide and 20 high ridge. The shape of the karst depression of Malo Drskovško jezero is unusual and is very reminiscent of a classical overflow karst polje. This roundshaped depression narrows into a small pocket valley with a high precipitous rock wall on its southeastern side. At the bottom of the wall is a several metre long horizontal cave called Podmou, which is the spring cave of Malo Drskovško jezero. During high waters, water comes out of several small holes and rubble which is accumulated at the bottom of the wall. The water outflows through a short channel to an oval-shaped depression where the lake occurs. When the discharge of the spring reduces, the water does not reach the abovementioned depression, but sinks into ponors located in the lower part of the channel, about $200 \mathrm{~m}$ before the main ponor. The major part of Malo Drskovško jezero empties into fissures in the bottom and, at higher water levels, mainly into a ponor cave on the northern side of the 


\section{KLENSKI DOL IN RADOHOVSKO JEZERO}

Klenski dol se ojezeri v majhni uleknini za vasjo, z dnom na $544 \mathrm{~m}$ n.v. To je skoraj 10 metrov nad strugo Pivke, ki se v velikem loku s spodnje strani povsem približa Kleniku, potem pa zavije proti zahodu do Radohove vasi. Polje med Klenikom in Radohovo vasjo je pogosto poplavljeno. Na dnu Klenskega dola, ki leži skoraj sredi vasi, so obdelane njive. Po površini sta Klensko in Radohovsko jezero običajno med najmanjšimi na Pivki, vendar je bil Klenski dol novembra 2000 približno desetkrat večji, kot je ob srednjem vodostaju.

Radohovsko jezero je edino jezero na levem bregu Pivke. Nastane v majhnem zatrepu ob vznožju Primoža in podzemno odteka v Pivko. $S$ treh strani ga obdajajo hiše in cesta, saj se Radohova vas (del naselja Pivka) širi. Podatek o srednji višini Radohovskega jezera, naveden $\mathrm{v}$ TTN 1:5000, je po našem prepričanju previsok, saj je najnižja točka oboda tega jezera na karti označena na nadmorski višini $536 \mathrm{~m}$. Če bi voda dejansko dosegla to višino, bi se prelivala preko ceste Pivka - Knežak proti strugi Pivke, kar pa se ne dogaja. Tudi ob izjemno visokih vodah novembra 2000 je vodna gladina dosegla komaj 535,6 m. Srednjo višino Radohovskega jezera bo torej potrebno popraviti.

\section{PALŠKO JEZERO}

Palško jezero je največje izmed vseh jezer na Pivki. Nastaja severno od Palčja, v poldrugi kilometer dolgi in pol kilometra široki globeli z uravnanim, naplavljenim dnom. Od struge Pivke je oddaljeno $2 \mathrm{~km}$ proti vzhodu. Najnižja točka Palškega jezera je na nadmorski višini $542,3 \mathrm{~m}$. Ob srednjem vodostaju (555 m) znaša njegova površina nekaj več kot $1 \mathrm{~km}^{2}$. Tedaj je $\mathrm{v}$ globeli okrog 7 milijonov $\mathrm{m}^{3}$ vode. Kadar se vodna gladina dvigne nad $552 \mathrm{~m}$, dobi jezero dva zaliva, imenovana Njivce in Ždink. Sredi med njima se dviga $606 \mathrm{~m}$ visok hrib Jezerščak. depression. This cave is also called Podmou. In contrast with the spring cave, which is covered mainly with rubble, the ponor cave is to a great extent filled with fine-grained sediments and its walls are partly sintered. In November 2000, the mean water level of Malo Drskovško jezero was exceeded by $4 \mathrm{~m}$ (as was also the case with Veliko Drskovško jezero) and its surface area doubled.

\section{PARSKO JEZERO}

The thirdin the line of the threeinterconnected lakes is Parsko jezero, which gathers water from Malo Drskovško jezero and emits it into a spring called Mišnik. This interconnection is indicated by relevant temperature and chemical data (Habič 1975). Due to its permanence and discharge the Mišnik karst spring is one of the most important karst springs along the Pivka river and was in former times efficiently used to power a water mill and a water-driven sawmill. As with Veliko Drskovško jezero, Parsko jezero is extended into a small bay on its northwestern side. In November 2000, the water level rose by $2 \mathrm{~m}$ above the average value, reaching an elevation of $542 \mathrm{~m}$ asl.

\section{KLENSKI DOL AND RADOHOVSKO JEZERO}

The Klenski dol lake occurs in a doline lying at the very edge of the village of Klenik, at an elevation of $544 \mathrm{~m}$ asl. The doline is situated nearly $10 \mathrm{~m}$ higher than the Pivka riverbed, which in a big curve reaches Klenik from the south and then bends westwards towards the village of Radohova vas. The field between Klenik and Radohova vas is frequently flooded. At the bottom of Kenski dol depression, which lies almost in the centre of village, there is arable land. By surface area, Klenski dol and the nearby Radohovsko jezero lake are usually among the smallest lakes in the Pivka valley. However, in November 2000, the surface area of Klenski dol was about 10 times larger than it 
Obilno deževje v novembru leta 2000 je na Palškem jezeru povzročilo izreden porast vodne gladine, kakršnega ni bilo že preko 70 let. Ker je obrobje Palškega jezera dokaj blago naklonjeno, je voda zalila mnogo večjo površino in po dolini Gabrje skoraj oblila hriba Jezerščak in Seljivec. Cesta v Jaklovkoje bila tedaj poplavljena na dveh mestih, kar se je najverjetneje zgodilo prvič, in sicer med Njivcami in Gabrjem v dolžini dobrih $300 \mathrm{~m}$, med Ždinkom in Seljivcem pa še dobrih 200 m. Površina Palškega jezera je presegla 1,9 $\mathrm{km}^{2}$, količina vode $\mathrm{v}$ globeli pa se je več kot potrojila.

Palško jezero dobiva vodo iz več izvirov. Najmočnejši med njimi je Matijeva jama na vzhodnem robu globeli, s stranskim vhodom na $546 \mathrm{~m}$ n.v. Dokler je vodna gladina jezera ne doseže, odteka iz jame manjši potok. Ko jezero tako naraste, da je celoten jamski vhod zalit, je bruhanje vode mogoče opazovati na vodni gladini, kjer nastajajo vodni mehurji. $\mathrm{Ob}$ upadanju gladine jezera Matijeva jama požira vodo, zato jo uvrščamo med kraške estavele.

Matijeva jama ima obliko brezna in $7 \mathrm{~m}$ nad stranskim še navpični vhod. V suhem obdobju je mogoče $v$ jami opazovati zniževanje nivoja podzemne vode. Doslej najnižji izmerjeni vodostaj je bil na $516 \mathrm{~m}$ n.v., kar je $30 \mathrm{~m}$ pod vhodom v jamo (Habič 1968). Glede na to, da je vodna gladina Palškega jezera pozimi 2000 dosegla 566 m n.v., znaša izmerjena razlika med najvišjo in najnižjo gladino kraške vode pri Palčju celih $50 \mathrm{~m}$. S skice Matijeve jame (Slika 15) je razvidno, da je bil doslej izmerjeni najvišji vodostaj Palškega jezera malo manj kot $558 \mathrm{~m}$, torej je bila ta višina leta 2000 presežena kar za $8 \mathrm{~m}$.

$\mathrm{Na}$ jugovzhodnem obrobju jezera leži jama Kužica, ki je prav tako estavela. Konec leta 2000 je Palško jezero seglo vse do manjše uleknine v zaledju Kužice. Voda je vrela na površje $\mathrm{v}$ nešteto drobnih izvirkih, raztresenih po travnikih, in pri tem izkoristila vsako špranjo, celo luknje v krtinah. is at mean water level.

The Radohovsko jezero lake is named after Radohova vas, a part of the town of Pivka, and is the only lake situated on the left bank of the Pivka river. It appears in a small pocket valley at the foothill of Primož and flows underground into the Pivka. As Radohova vas is expanding, the lake is surrounded by buildings and a road on three sides. The value of the mean water level of the lake indicated in the BTM 1:5000, is, according to our observations, slightly overestimated, since the map shows that the lowest point of the edge of the lake lies at $536 \mathrm{~m}$ asl. If the water actually reached this elevation, the Pivka - Knežak road would be flooded, which, never happens. Even in November 2000, during exceptionally high waters, the water level of Radohovsko jezero hardly reached an elevation of $535.6 \mathrm{~m}$ asl, meaning that the average water level of Radohovsko jezero needs to be determined again.

\section{PALŠKO JEZERO}

Palško jezero is the largest of all periodical lakes in the Pivka valley and occurs in a $1.5 \mathrm{~km}$ long and $0.5 \mathrm{~km}$ wide shallow karst depression situated $2 \mathrm{~km}$ to the east of the Pivka river. The lowest point of its rather level alluvial bottom lies at an elevation of $542.3 \mathrm{~m}$ asl. At mean water level (555 $\mathrm{m}$ asl), the surface area of the lake covers more than $1 \mathrm{~km}^{2}$, while the volume of water is 7 million $\mathrm{m}^{3}$. When the water level rises above $552 \mathrm{~m}$ asl, two bays (called Njivce and Ždink respectively) form. Between them is a hill called Jezerščak (606 m asl).

In November 2000, abundant precipitation caused an exceptional increase in the water level, for the first time after more than 70 years. As the margin of the lake is only slightly inclined, the water flooded a much larger area and almost surrounded the hills Jezerščak and Seljivec along the Gabrje valley (Habič 2005). At that time, the macadam road leading to Jaklovka was flooded at two sections (between 
Iz Palškega jezera voda podzemno odteka skozi Matijevo jamo, Kužico ter požiralnike na dnu globeli v Trnske izvire, od tam dalje po kratkem površinskem toku kot Stržen in Tršnica doseže Pivko.

\section{PETELINJSKO JEZERO}

Ob vznožju Okrogleka, podaljšanega hrbta Sv. Trojice (Javorniki), leži v ovalni globeli Petelinjsko jezero, z dnom na nadmorski višini $532 \mathrm{~m}$. To jezero je najbolj obstojno, saj se voda v njem zadržuje tudi do pol leta (Habič 1975). S površino okrog $700000 \mathrm{~m}^{2}$ zaostaja le za Palškim jezerom. Voda privre na površje v talnih izvirih na južnem delu jezera, ponikne pa skozi prepustna tla na južnem in na severnem koncu. Od tod se voda pretaka v Žejske izvire in po kratkem površinskem toku doseže Pivko. Ko se Petelinjsko jezero osuši, presahnejo tudi Žejski izviri.

Kljub temu da so novembra 2000 izjemne padavine povzročile porast vodostajev skoraj v vseh 17 jezerih v dolini Pivke, je v najnižje ležečem Petelinjskem jezeru najvišji vodostaj kar za 4 m zaostal za srednjim. To daje slutiti, da je podatek o srednjem vodostaju označenem na TTN 1:5000 (545 m) previsok. Tudi Habič (1975) navaja, da je ta višina Petelinjskega jezera le redko dosežena.

\section{KRAJNIKOV DOL IN JEREDOVCE}

Najbolj severno, zadnje v vrsti presihajočih Pivških jezer, so Jeredovce. To je potegnjena, z blagimi pobočji obrobljena globel nad Žejami, z dnom na 537 m n.v. Enako visoko, a malo južneje leži Krajnikov dol. Tako Jeredovce kot Krajnikov dol se napolnita le ob najvišjih vodah. Žejci dobro vedo, kdaj je v Jeredovcah jezero. Tedaj namreč precej nižje, v bližini vasi, oživi izvir Šulk in se po kratkem hudourniškem toku razlije po njivah.
Njivce and Gabrje over a length of $300 \mathrm{~m}$ and between Ždink and Seljivec over a length of 200 $\mathrm{m})$, which probably happened for the first time in history. The surface area of the lake exceeded $1.9 \mathrm{~km}^{2}$ and its volume increased more than three times.

Palško jezero gathers water from several karst springs, among which Matijeva jama (an estavelle) is the strongest. The cave is situated on the east edge of the depression, its side entrance being at $546 \mathrm{~m}$ asl. Until the cave is reached by the water of the lake, a small stream flows from it. When the water level of the lake rises to the elevation of the cave so that the entrance is completely under water, from bubbles on the surface it can be seen that cave water is still bursting out. During lowering of the lake's water level, the cave acts as a ponor, so it is classified as an estavelle.

As far as its shape is concerned, Matijeva jama is an abyss with a vertical entrance situated $7 \mathrm{~m}$ above the side entrance. In the dry season, the dropping of the underground water level can be observed in the cave. The lowest water level recorded so far is at $516 \mathrm{~m}$ asl, i.e. $30 \mathrm{~m}$ below the entrance of the cave (Habic 1968). Considering the fact that in November 2000 the maximum water level of Palško jezero was at $566 \mathrm{~m}$ asl, the difference between the highest and lowest recorded water levels is as much as $50 \mathrm{~m}$. As shown on the plan of Matijeva jama (Figure 15), the maximum water level previously recorded was slightly less than 558 $\mathrm{m}$, which means that in November 2000 this level was exceeded by $8 \mathrm{~m}$.

On the southeastern margin of the lake, lies a cave called Kužica, which also is an estavelle. In November and December 2000, the Palško jezero lake stretched as far as a small shallow depression situated behind Kužica cave. Water was bursting to the surface from numerous springs on the meadows, whereby taking advantage of every single hole, even those of molehills. 
V nekdaj rodovitnih Jeredovcah so ob osnovanju vojaškega vadišča Poček opustili kmetovanje. Globel se je $\mathrm{v}$ minulih treh desetletjih že pošteno zarasla $\mathrm{z}$ drevjem in grmičevjem, zato je vodna gladina jezera skrita med krošnjami. Novembra 2000 je dosegla 542 $\mathrm{m}$ n.v., podatka o srednjem vodostaju tako $\mathrm{v}$ Jeredovcah kot v Krajnikovem dolu pa ni. Dolina Jeredovc se od najnižjega dela, kjer nastaja jezero, polagoma dviga proti severovzhodu. $\mathrm{Na}$ dnu je nanizanih nekaj večjih in manjših vrtač. Novembra 2000 se je voda pojavila kar v šestih izmed njih, pri čemer je najvišje, do 546 m n.v., segla v dveh najbolj severovzhodno ležečih vrtačah.

\section{ZAKLJUČEK}

Posebne geološke razmere v dolini Zgornje Pivke omogočajo pogosto pojavljanje vode $\mathrm{v}$ globelih z dnom na relativno nizkih nadmorskih višinah. Presihajoča jezera nastajajo V sedemnajstih globelih. Dejavnikov, ki vplivajo na pogostost in trajanje posameznega jezera, je več: bližina gladine kraške podtalnice, nadmorska višina dna globeli, relativna višina in horizontalna oddaljenost od struge Pivke, velikost napajalnega zaledja, prevotljenost kraškega zaledja ter odtočnega območja jezera, količina padavin $\mathrm{v}$ določenem časovnem obdobju in še kaj.

Celoten hidrološki sistem presihajočih jezer na Zgornji Pivki je izjemen v slovenskem krasu, v vseh njegovih razsežnostih pa ga je bilo mogoče opazovati novembra in decembra leta 2000. Nenavadno visoke novembrske padavine, ki so ponekod kar za trikrat presegle povprečne mesečne vrednosti, so povzročile izjemen porast nivoja podtalnice na Zgornji Pivki in posledično visoke poplavne vode $\mathrm{v}$ jezerskih in drugih globelih oziroma nižje ležečih območjih. Vodostaji vseh sedemnajstih presihajočih jezer so bili tako prvič izmerjeni in dokumentirani, prav tako vse poplavne vode, razen tistih vzdolž same struge Pivke, kjer so poplave reden pojav. Tako visokih voda domačini ne pomnijo vsaj 70
The lake empties through the Matijeva jama and Kužica caves as well as through swallow holes at the bottom of the depression. The water then re-emerges at the Trnje karst springs and continues flowing towards the Pivka river as a surface stream under the names of Stržen and Tršnica.

\section{PETELINJSKO JEZERO}

At the end of Okroglek, the extended ridge of Sv. Trojica (the Javorniki plateau) lies an ovalshaped depression called Petelijnsko jezero, with its bottom at an altitude of $532 \mathrm{~m}$. This lake is the most long-lasting of all lakes in the Pivka valley and remains for up to six months (Habič 1975). With its surface area of about $700000 \mathrm{~m}^{2}$, it is the second largest lake after Palško jezero. The water bursts to the surface from springs located at the bottom of the southern part of the depression, and sinks mainly through sinkholes in the northern part. From there it runs towards the Žeje karst springs and onwards to the Pivka river. When Petelinjsko jezero dries out, the Žeje karst springs also run dry.

While in November 2000 heavy precipitation caused an increase in the water level of almost all the 17 lakes in the Pivka valley, the water level of Petelinjsko jezero was $4 \mathrm{~m}$ below the stated average. From this it can be concluded that the data on the mean water level as shown on the BTM 1:5000. (545 m asl) is overestimated. Habič (1975) also mentions that the lake only rarely reaches this elevation.

\section{KRAJNIKOV DOL AND JEREDOVCE}

The most northerly and the last in the line of the Pivka intermittent lakes is the Jeredovce lake. This is a shallow depression stretching along the village of Žeje, with its bottom at $537 \mathrm{~m}$ asl. Situated at the same elevation, but slightly farther to the south, is another lake called Krajnikov dol. Both depressions are flooded only during high waters. The people 
let.

Primerjava najvišjih vodostajev iz leta 2000 s srednjimi vodostaji jezer pokaže, da so relativne višinske razlike odvisne od oblikovanosti jezerske globeli in hkrati v tesni povezanosti $\mathrm{z}$ njenim položajem ter oddaljenostjo od struge reke Pivke proti zaledju. Skupna vodna površina sedemnajstih Pivških presihajočih jezer je v novembru 2000 znašala $3,33 \mathrm{~km}^{2}$, od tega je $1,9 \mathrm{~km}^{2}$ merilo največje Palško jezero. Dokumentirani podatki o vodostajih, površinah in prostorninah jezer ter ostalih poplavljenih globeli na Zgornji Pivki v času visokih voda novembra 2000 so ključni za razumevanje delovanja hidrološkega sistema presihajočih jezer ter dobra osnova za njegovo nadaljnje preučevanje. Čeprav so ojezeritve $\mathrm{v}$ glavnem posledica dejstva, da je napajanje mnogo izrazitejše od praznjenja, pa opazne razlike v vodostajih jezer, ki ležijo blizu drug drugemu, dokazujejo, da navidezno sicer enostaven hidrološki sistem kljub vsemu v sebi skriva še veliko neznank. $Z$ namenom boljšega poznavanja vodnega režima posameznih jezer ter celotnega sistema jezer bi bile potrebne sistematične raziskave, opazovanja in meritve ojezerjenih površin $\mathrm{v}$ času njihovega pojavljanja. of Žeje know well when there is a lake in the Jeredovce depression, because the Šulk karst spring situated near the village is active at that time, overflowing the nearby meadows and fields.

Due to military training activities in the wider area, the cultivation of the Jeredovce depression has been abandoned. As a result, the depression has become overgrown by trees and bushes in the past three decades, and the lake (when it appears) is now hidden under tree crowns. In November 2000, the water level of the lake reached an elevation of $542 \mathrm{~m}$ asl; however, there are no figures on the mean water levels of Jeredovce and Krajnikov dol available. From its lowest part, where the lake occurs, the valley of Jeredovce gradually rises towards the northeast. At its bottom, there is a series of dolines. In November 2000, as many as six of these were flooded, and the water level reached the highest point $(546 \mathrm{~m}$ asl) in the two which lie farthest to the northeast.

\section{CONCLUSION}

Due to special geological conditions in the Upper Pivka valley, its shallow karst depressions, which are situated at relatively low elevations, are often flooded. Intermittent karst lakes occur in seventeen karst depressions. There are several factors affecting the duration of a particular lake and the frequency of its occurrence: the depth of karst groundwater, the elevation of the karst depression, difference in height and horizontal distance between the depression and the Pivka riverbed, the extent of the recharge area, the permeability of the subsurface recharge and discharge areas of the lake, the amount and intensity of precipitation during a particular period, etc.

The entire system of the seventeen periodical lakes in Upper Pivka is unique in Slovenian karst. In November and December 2000, the phenomenon was revealed in its full extent. In November 2000, the amount of precipitation 
somewhere was more than three times the average, which resulted in a great increase in the level of the water table in Upper Pivka and consequently caused the strong flooding of lake depressions and other depressions as well as other lower lying areas. For the first time in history, the water levels of all seventeen lakes were measured and recorded, as well as the water levels of all flooded areas, except the ones along the Pivka riverbed. According to local people, such high waters appeared for the first time in 70 years.

The comparison between the maximum water levels of the lakes recorded in November 2000 and the mean water levels shows that differences in height between them are dependent on the shape and location of the lake depression and its distance from the Pivka riverbed. In November 2000, the total surface area of the seventeen Pivka periodical lakes amounted to $3.33 \mathrm{~km}^{2}$ (the Palško jezero lake $=1.9 \mathrm{~km}^{2}$ ).

Recorded data on the water levels, surface areas and the volumes of the lakes and other flooded areas in Upper Pivka during the high waters of November 2000 are essential for a better understanding of the lakes' hydrological system and at the same time represent a good foundation for further investigation and interpretation. Although the formation of intermittent lakes is basically the consequence of the fact that underground recharging is stronger then subsurface runoff from the region, the noticeable differences in the water levels of lakes lying close one to another prove that there is still too little known about such an apparently simple hydrological system. In order to understand better the hydraulic regime of individual lakes and the entire system of the lakes, systematic investigations, observations and measurements of the lakes are necessary. 


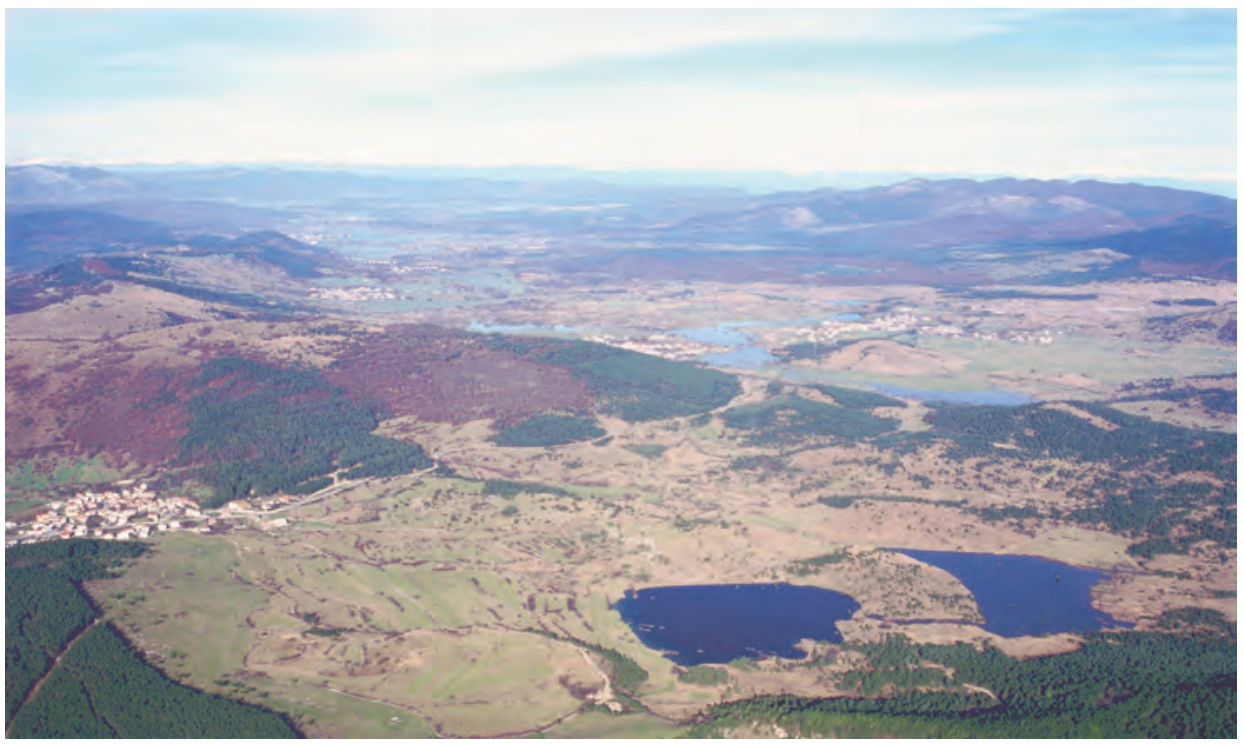

Slika 5: Šembijsko jezero (levo) in Nariče (Foto: Š. Habič).
Figure 5: Šembijsko jezero (left) and the Nariče depression (Photo: Š. Habič).

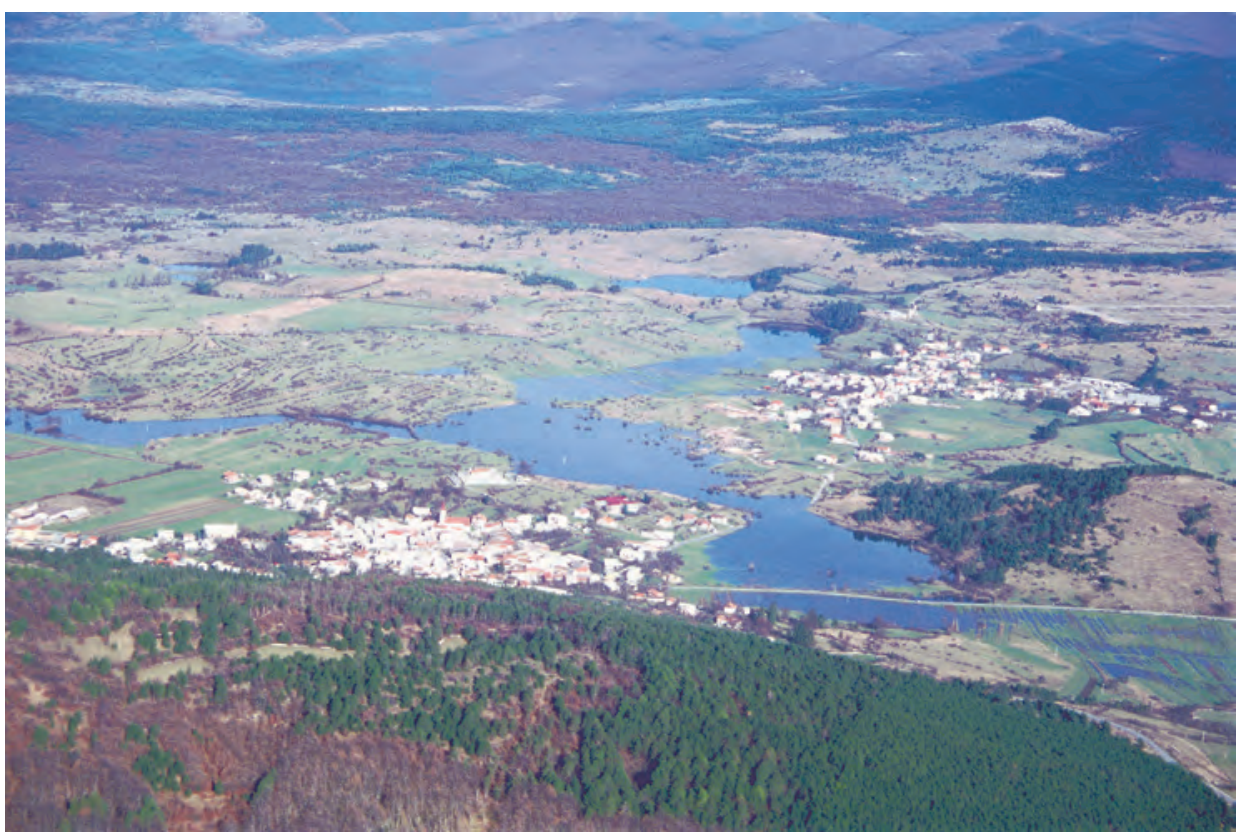

Slika 6: Poplavno območje v okolici Knežaka in Bača (Foto: Š. Habič).
Figure 6: Flooding area around Knežak and Bač (Photo: $\breve{S}$. Habič). 


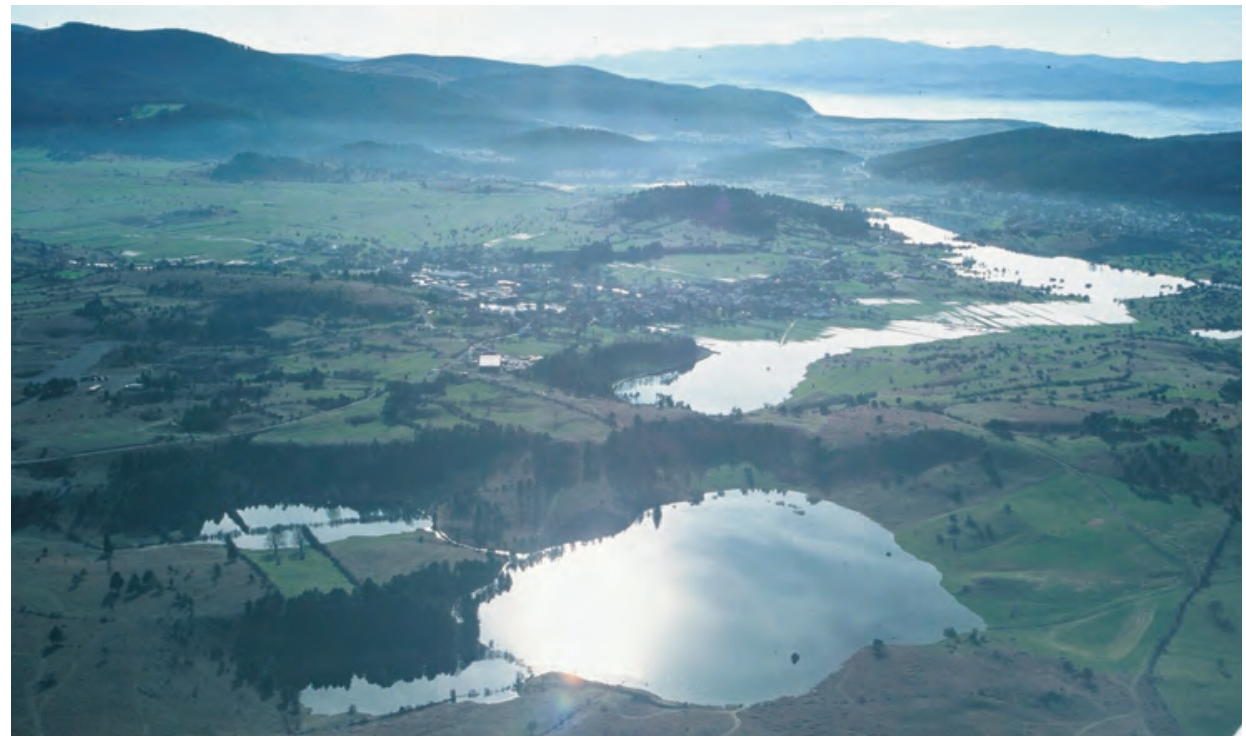

Slika 7: Laneno jezero (levo) in Bačko jezero. V ozadju so poplavljene površine v okolici Knežaka in Bača (Foto: Š. Habič).
Figure 7: Laneno jezero (left) and Bačko jezero. In the background is the flooding area around Knežak and Bač (Photo: S̆. Habič).

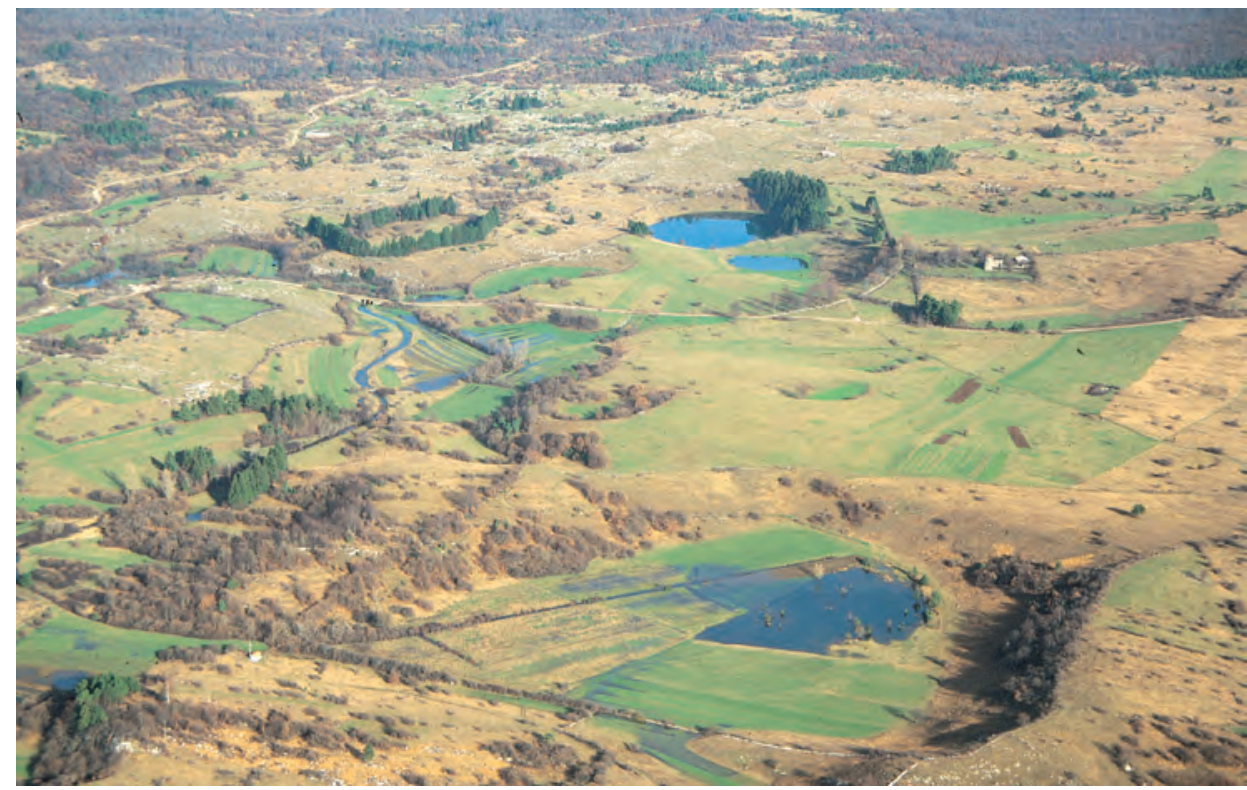

Slika 8: Od spodaj navzgor si sledijo Kalsko jezero, Kljunov ribnik (blizu struge Pivke) in Veliki dol (za Kalcem) s poplavljeno vrtačo v njegovi bližini (Foto: S̆. Habič).
Figure 8: From the bottom upwards are Kalsko jezero, Kljunov ribnik (near the Pivka riverbed) and Veliki dol (za Kalcem) with a flooded doline in its vicinity (Photo: Š. Habič). 


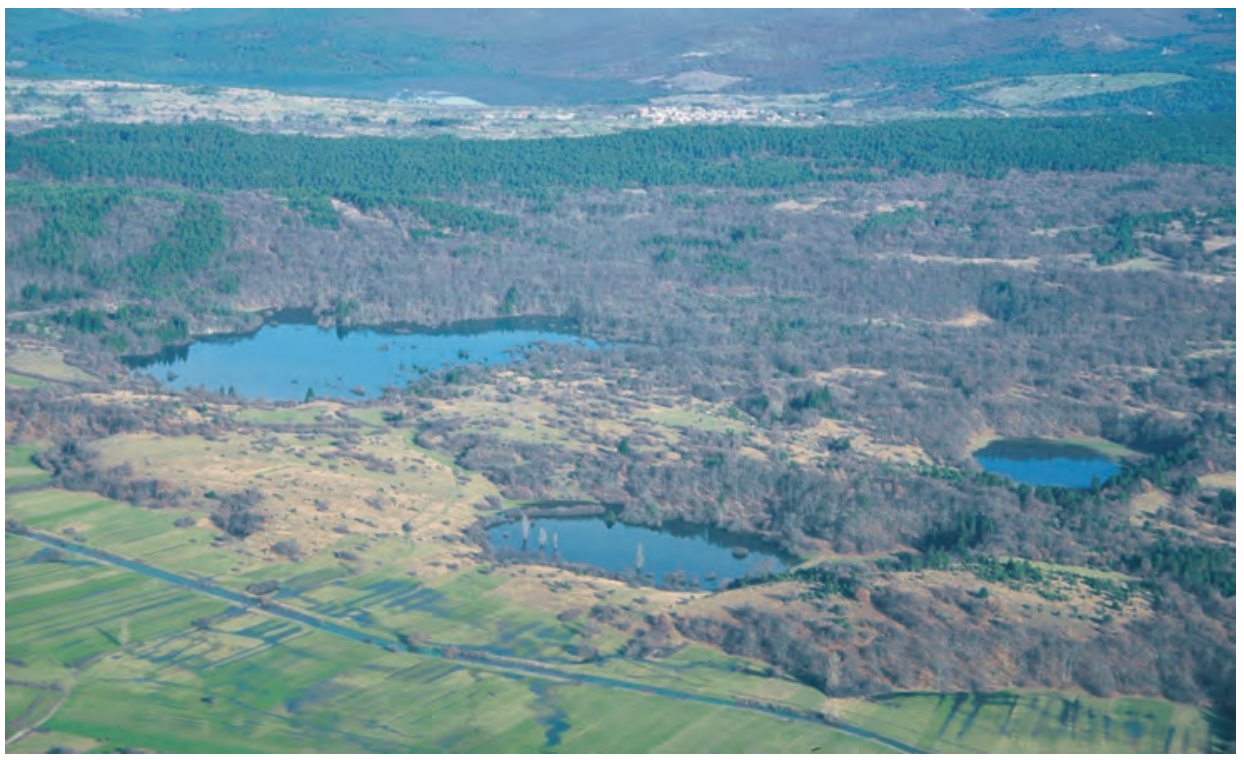

Slika 9: Od desne proti levi si sledijo Veliko Zagorsko jezero, Malo Zagorsko jezero in Veliko Drskovško jezero, zgoraj Palško jezero (Foto: Š. Habič).
Figure 9: From right to left are Veliko Zagorsko jezero, Malo Zagorsko jezero and Veliko Drskovško

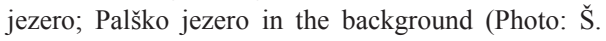
Habič).

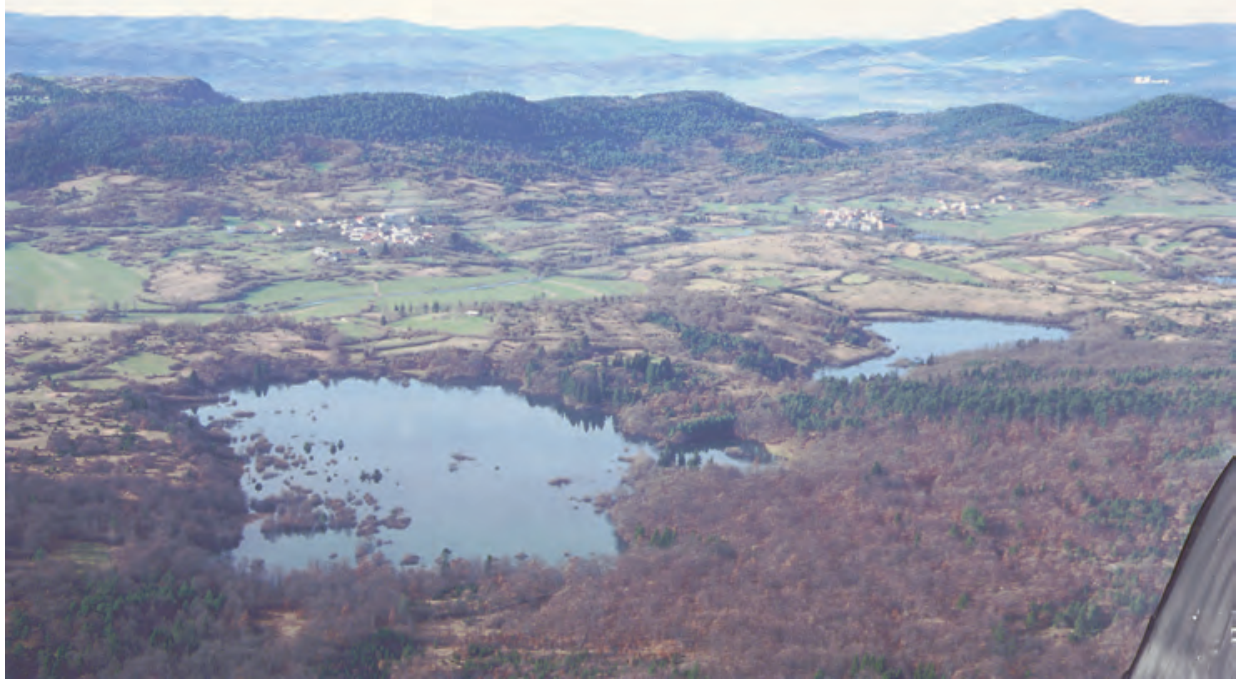

Slika 10: Veliko in Malo Drskovško jezero (Foto: Š. Habič).
Figure 10: Veliko Drskovško jezero and Malo Drskovško jezero (Photo: Š. Habič). 


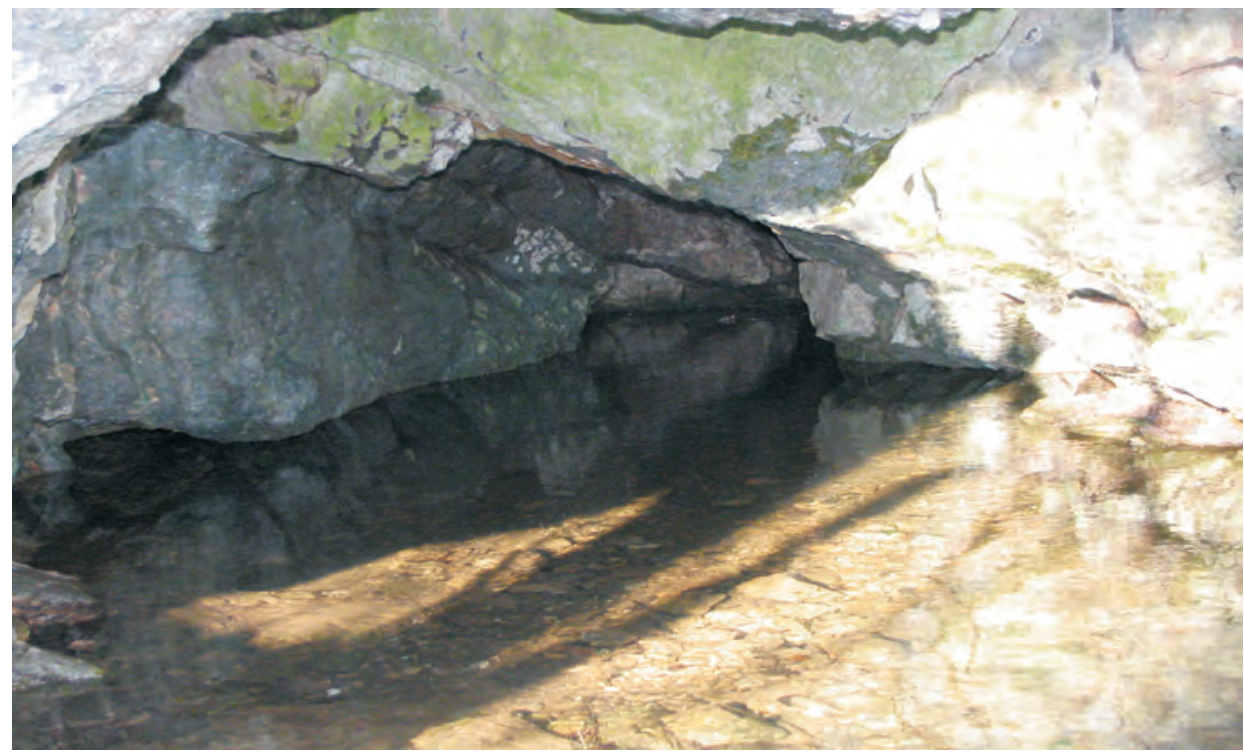

Slika 11: Podmou - manjši vodoraven ponor na severozahodnem robu kotanje Malega Drskovškega jezera (Foto: G. Kovačič).
Figure 11: Podmou - a small horizontal ponor cave situated on the northwestern edge of the Malo Drskovško jezero depression (Photo: G. Kovačič).

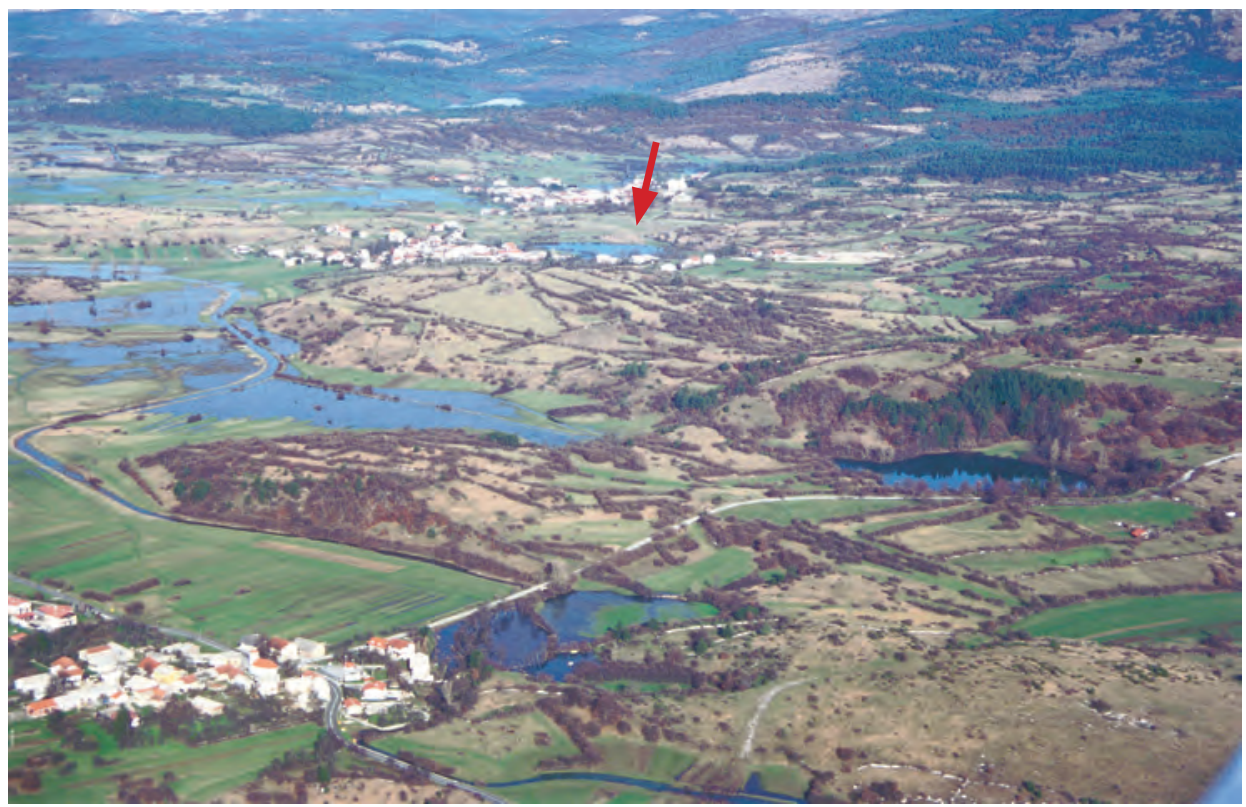

Slika 12: Poplave vzdolž struge Pivke s Parskim jezerom (desno) in Klenskim dolom $\mathrm{v}$ ozadju (označeno) (Foto: Š. Habič).
Figure 12: Floods along the Pivka riverbed with Parsko jezero (right) and Klenski dol in the background (marked) (Photo: Š. Habič). 


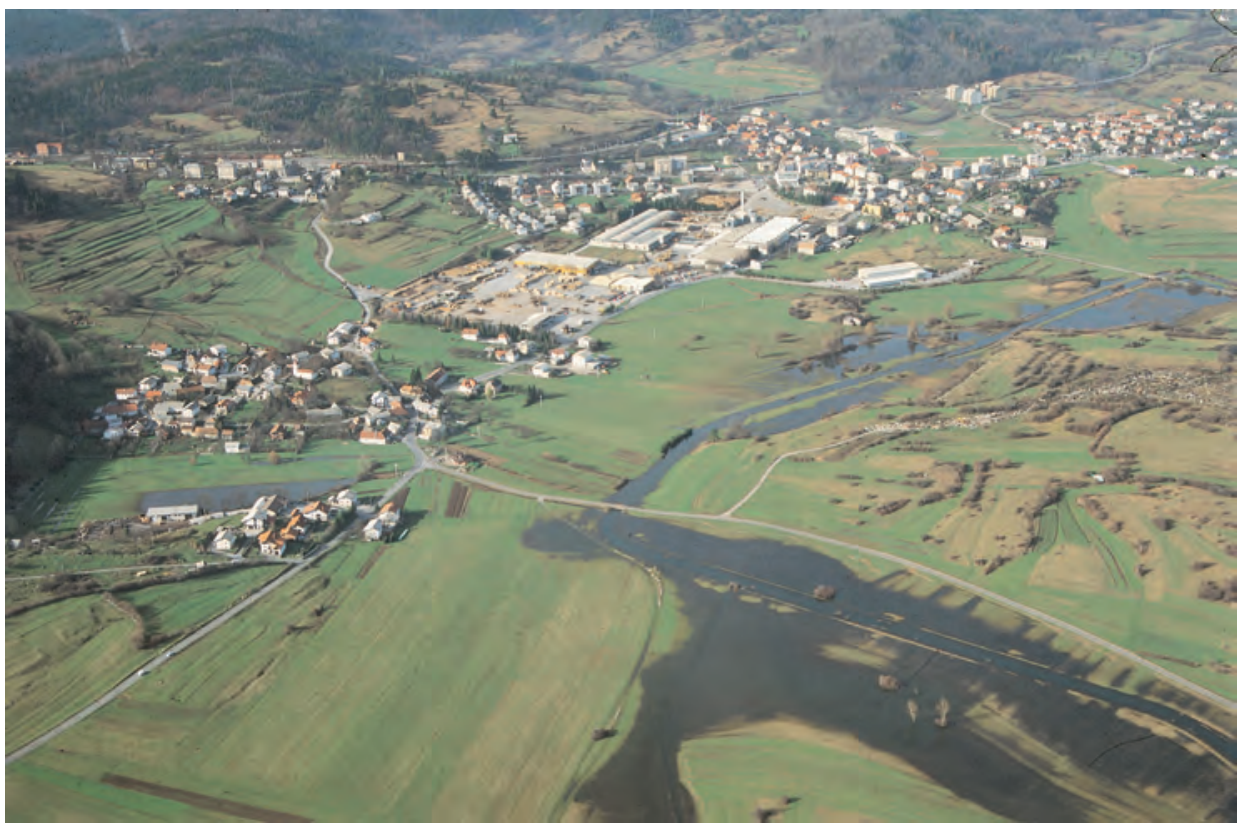

Slika 13: Radohovsko jezero (levo) in struga Pivke (desno) (Foto: Š. Habič).
Figure 13: Radohovsko jezero (left) and the Pivka riverbed (right) (Photo: Š. Habič).

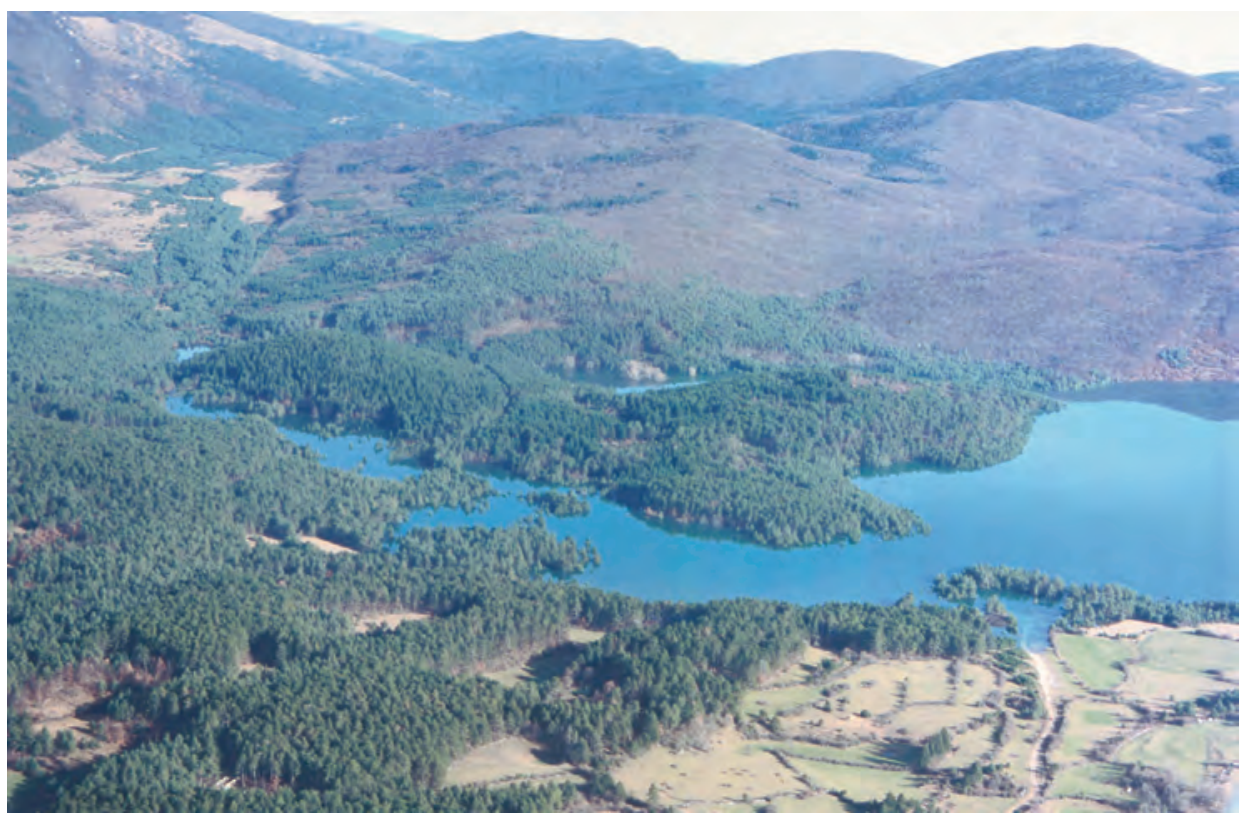

Slika 14: Palško jezero z zalivoma Ždink in Njivce (Foto: Š. Habič).
Figure 14: Palško jezero with the Ždink and Njivce bays (Photo: S̆. Habič). 


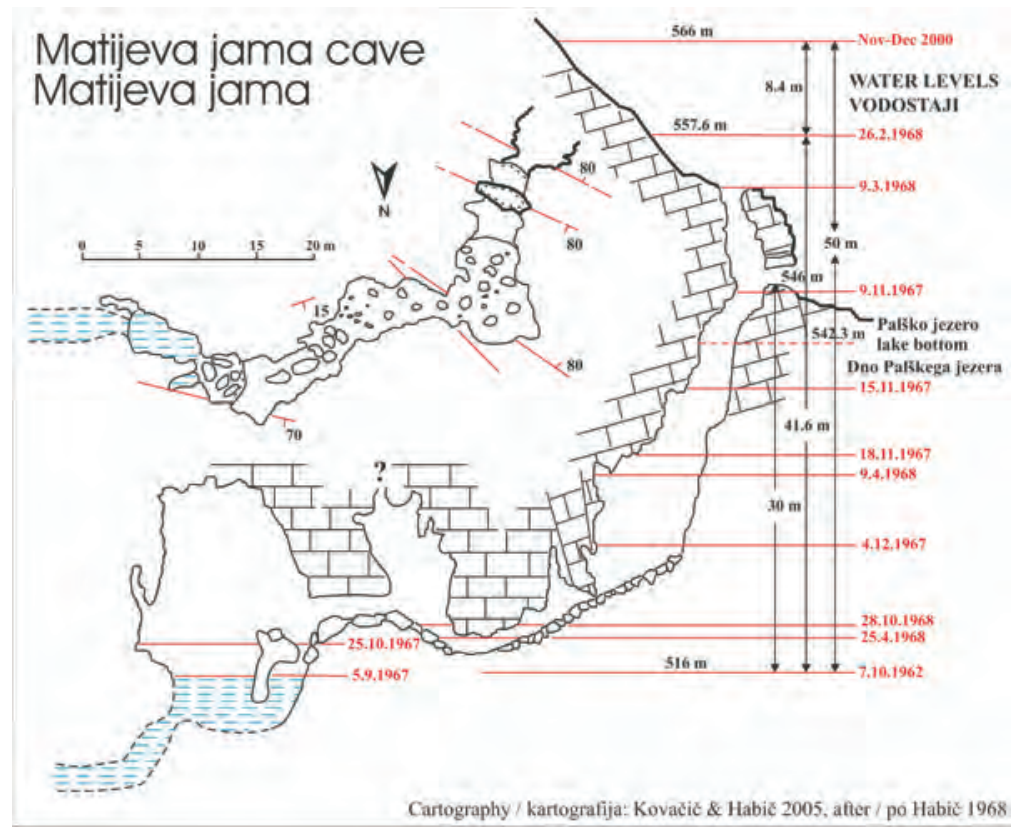

Slika 15: Načrt Matijeve jame (Palško jezero) z izmerjenimi vodostaji.

Figure 15: Matijeva jama (Palško jezero) with measured water levels.

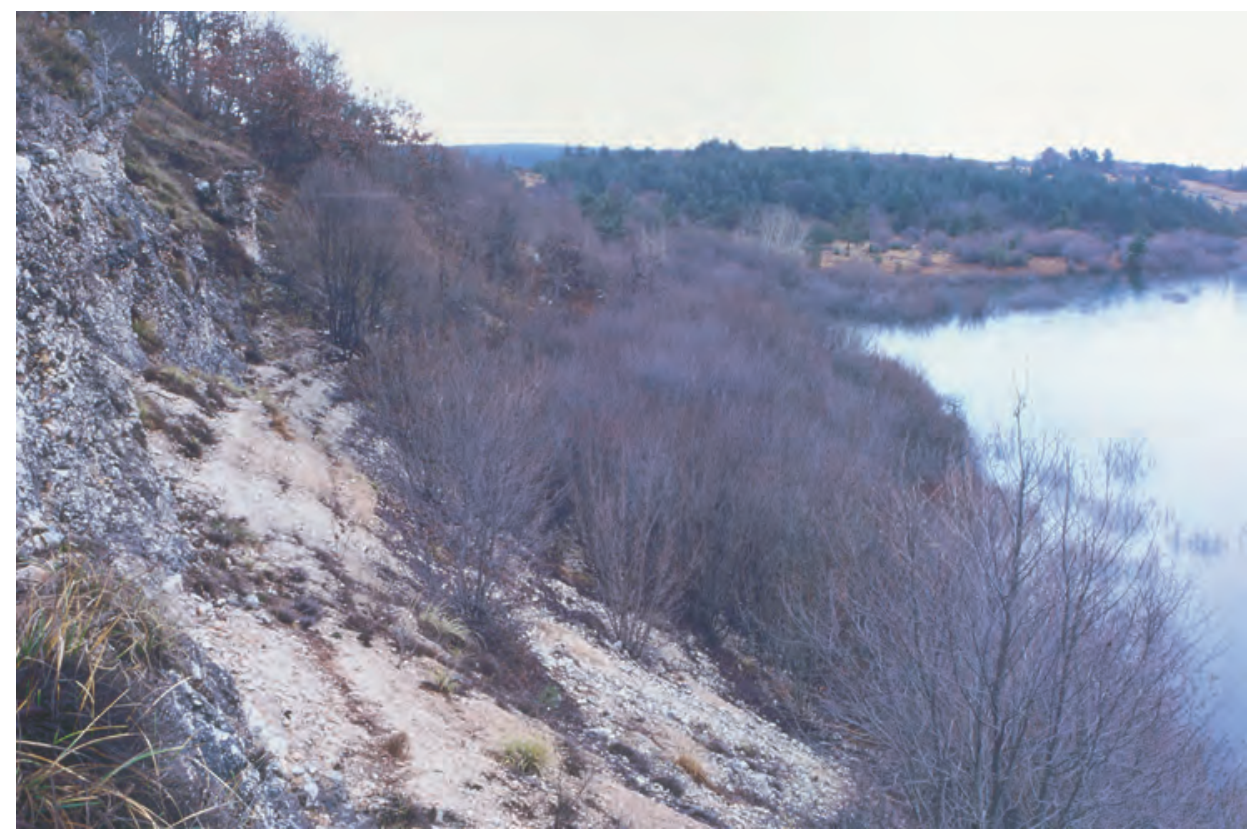

Slika 16: Naplavine na bregu dokazujejo veliko višji vodostaj Palškega jezera, kot ga prikazuje fotografija (Foto: $\breve{S}$. Habič).
Figure 16: Sediments on the shore giving evidence of a much higher water stage of the Palško jezero lake

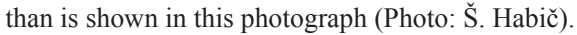




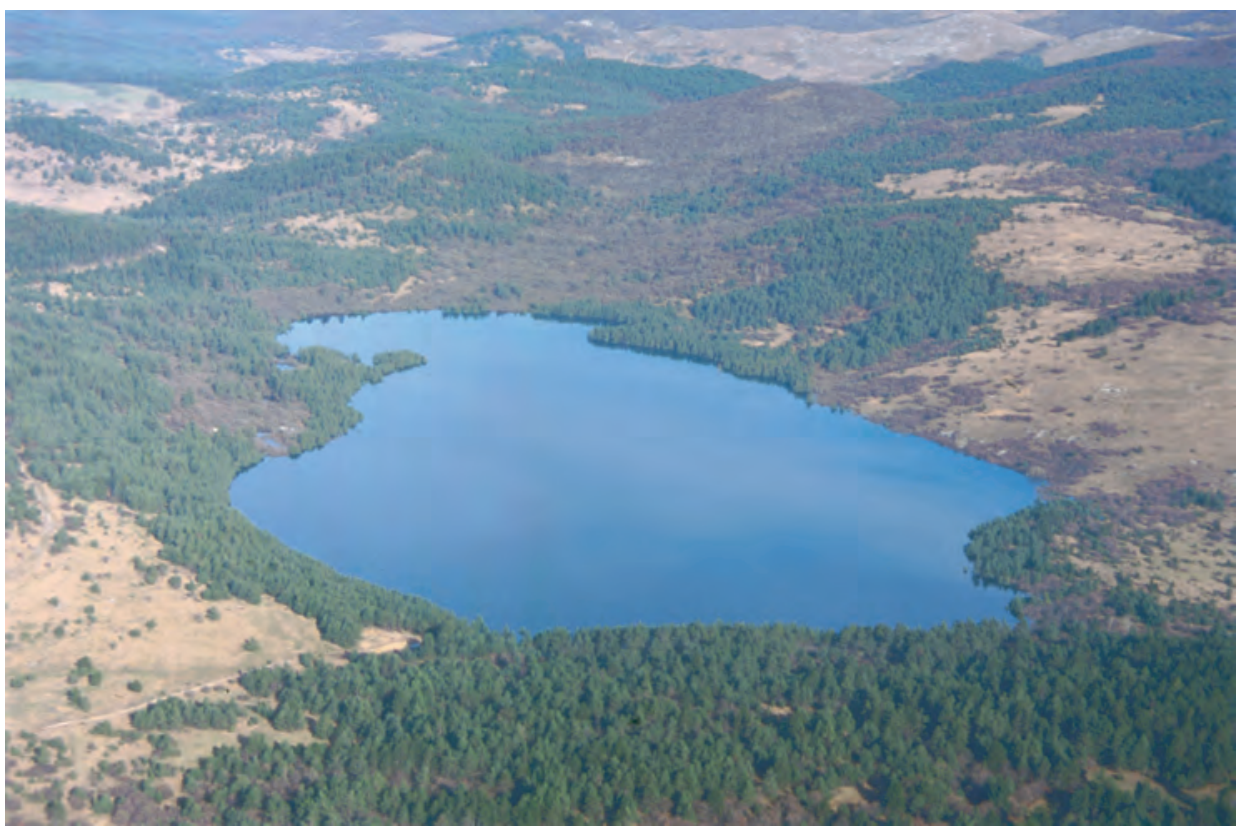

Slika 17: Petelinjsko jezero (Foto: Š. Habič).

Figure 17: Petelinjsko jezero (Photo: S̆. Habič).

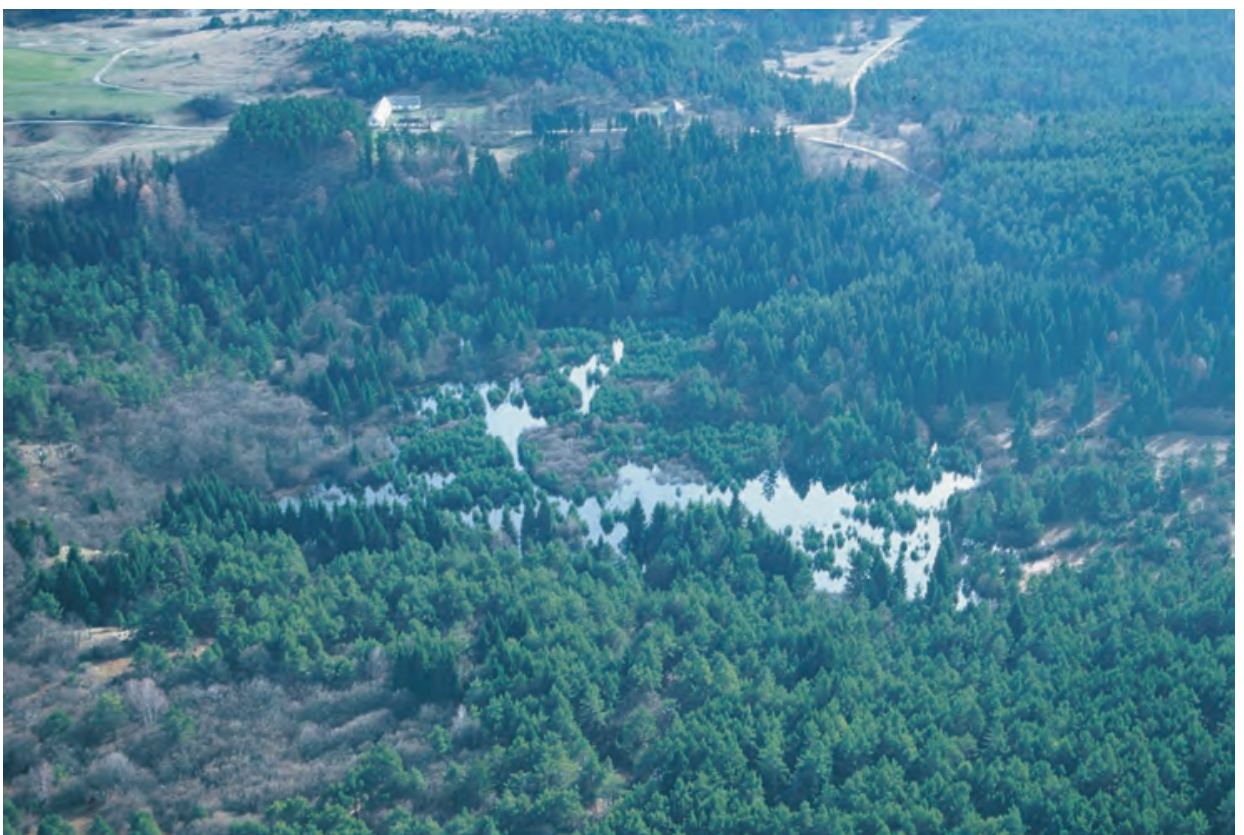

Slika 18: Jezero Jeredovce je skrito pod krošnjami dreves (Foto: Š. Habič).
Figure 18: Jeredovce lake is hidden beneath the tree crowns (Photo: $\breve{S}$. Habič). 


\section{LITERATURA - REFERENCES}

Dolinar, M., 2000/2001: Obilne padavine v letih 1999 in 2000.- Ujma, 14-15, 32-38, Ljubljana.

Habič, P., 1968a: Kraško porečje Zgornje Pivke in javorniški podzemeljski tok. Vodni viri za oskrbo Postojne.- Inštitut za raziskovanje krasa ZRC SAZU, 50-101, Postojna.

Habič, P., 1968b: Javorniški podzemeljski tok in oskrba Postojne z vodo.- Naše jame, 10, 47-54, Ljubljana.

Habič, P., 1975: Pivka in njena kraška jezera.- In: Fatur, S., \& R. Gospodarič (eds.), Ljudje in kraji ob Pivki 1, Kulturna skupnost Postojna, 41-54, Postojna.

Habič, P, 1985: Water table in Slovene karst of Notranjsko and Primorsko.- Acta carsologica, 13, 37-78, Ljubljana.

Habič, Š., 2005: Pivka, dolina presihajočih jezer.- Vrhniški razgledi 6, Vrhniško muzejsko društvo, Vrhnika (in print).

Krivic, P., Juren, A., Bizjak, M. \& B. Ravnikar, 1983: Hidrogeološke raziskave zaledja Zgornje Pivke, I. faza.- Geološki zavod Ljubljana, TOZD-I geologija, geotehnika, geofizika, p. 10, Ljubljana.

Markošek, J. \& J. Polajnar, 2000/2001: Obilne padavine in visoke vode novembra 2000.- Ujma, 14-15, 137-141, Ljubljana.

Placer, L., 1981: Geološka zgradba jugozahodne Slovenije.- Geologija, 24/1, 27-60, Ljubljana.

Podatki o padavinah za padavinske postaje Postojna, Ilirska Bistrica in Jurišče, 2000. Arhiv ARSO, Ljubljana.

Pleničar, M., 1959: Tektonski okni pri Knežaku.- Geologija, 5, 5-10, Ljubljana.

Ravbar, N. \& S. Šebela, 2003: The karst periodical lakes of Upper Pivka, Slovenia.- Acta carsologica, 33, 1, 159-173, Ljubljana.

Zupančič, B., 1995: Klimatografija Slovenije 1961-1990, Padavine.- MOP-Hidrometeorološki zavod Republike Slovenije, p. 366, Ljubljana. 